\title{
The genus Cyperus (Cyperaceae) in Rio Grande do Norte State, Brazil
}

\author{
André Rodolfo de Oliveira Ribeiro ${ }^{1,6}$, Marccus Alves ${ }^{2}$, Ana Paula do Nascimento Prata ${ }^{3}$, Odaci Fernandes \\ de Oliveira ${ }^{4}$, Leandro de Oliveira Furtado de Sousa ${ }^{5}$, Regina Célia de Oliveira ${ }^{5}$
}

\begin{abstract}
Cyperus is a Pantropical genus and the second richest in species in Cyperaceae. It encompasses about 550 species worldwide, with about 100 of these occurring in Brazil. Studies on the taxonomy of this genus are scarce and punctual in Brazil. In this study, the occurrence of species was surveyed through 27 collecting expeditions across different regions in the state of Rio Grande do Norte and analyzis of specimens of several herbaria. Twenty four species of Cyperus were identified, including six new occurrences and one new species, here described, but that will be properly published in other work. This study includes a dichotomous key for the identification of the species, as well as illustrations, descriptions, taxonomic comments and geographical distribution.
\end{abstract}

Key words: Cyperoideae; Taxonomy; Monocots.

\section{Introduction}

Cyperaceae is a cosmopolitan family represented by about 5,500 species (Govaertz et al. 2014), with about 650 of these occurring in Brazil (Alves et al. 2014). Recent studies reportedly subdivided this family into two clades, which are represented by the subfamilies Mapanioideae and Cyperoideae (Simpson et al. 2007; Muasya et al. 2009a, 2009b). Among Cyperoideae, the tribe Cypereae may be subdivided into two subclades (Larridon et al. 2013): one - "Ficinia Clade", with about 160 species - represents the species of southern Africa, the majority of these bearing spirally arranged glumes; the other -"Cyperus Clade", with about 950 species - represents the Pantropical species, most of them with distichous glumes.

The circumscription of Cyperus L. inside the Cyperus Clade has been non-consensual. Kükenthal (1936) and Haines \& Lye (1983) accepted Cyperus sensu lato and treated some taxa, as Kyllinga Rottb. and Pycreus P. Beauv., as of infrageneric rank. On the other hand, Goetghebeur (1998) kept Kyllinga,
Pycreus and other taxa at generic level and proposed Cyperus sensu stricto encompassing two subgenera, that is, Cyperus (including the species with C4 photosynthetic pathway) and Anosporum (Nees) C.B. Clarke (including the species with C3 photosynthetic pathway).

Recently, phylogenetic studies by Larridon et al. (2011a, 2011b, 2011c, 2013) led to the proposition of a more comprehensive classification, which demonstrates that Cyperus is paraphyletic and the "Cyperus Clade" encompasses at least 13 genera. In the subclade Cyperus C3, it was included the genera Courtoisina Soják, Oxycaryum Nees and Kyllingiella R.W. Haines \& Lye; in the subclade Cyperus C4, it was included nine genera, viz., Alinula J. Raynal, Ascolepis Nees ex Steud., Lipocarpha R. Br., Kyllinga Rottb., Pycreus P. Beauv., Queenslandiella Domin, Remirea Aubl., Sphaerocyperus Lye, and Volkiella Merxm. \& Czech.

Since the results from the phylogenetic studies by Larridon et al. (2011a, 2011b, 2011 c, 2013) have not yet been incorporated into the nomenclature of Cyperus, the taxonomic classification used in

\footnotetext{
${ }^{1}$ Universidade de Brasília, Inst. Ciências Biológicas, Depto. Botânica, Campus Universitário Darcy Ribeiro, 70910-900, Brasília, DF, Brazil.

${ }^{2}$ Universidade Federal de Pernambuco, Centro de Ciências Biológicas, Depto. Botânica, Av. Moraes Rego s/n, UFPE, CCB, 50940-000, Recife, PE, Brazil. Temporary Address: Herbarium Senckenberg Naturmuseum, Frankfurt am Main, 60325. Germany.

${ }^{3}$ Universidade Federal de Sergipe, Centro de Ciências Biológicas e da Saúde, Campus Universitário Professor Aloísio de Campos, 49100-000, Aracaju, SE, Brazil.

${ }^{4}$ Universidade Federal Rural do Semi-Árido, Depto. Ciências Vegetais, Av. Francisco Mota 572, Bairro Costa e Silva, 59.625-900, Mossoró, RN, Brazil.

${ }^{5}$ Universidade de Brasília, Inst. Ciências Biológicas, Depto. Botânica, C.P. 04457, 70.919-970, Brasília, DF, Brazil.

${ }^{6}$ Author for correspondence: andre rodolf@hotmail.com.
} 
the Flora of Brazil (Alves et al. 2014), as well as in most of the regional studies (Araújo \& Longhi-Wagner 1996; Luceño et al. 1997; Hefler \& Longhi-Wagner 2012), follows that proposed by Goetghebeur (1998). The present study also followed this classification and included in the taxonomic treatment the Cyperus s. s. species as treated by Goetghebeur (1998).

The genus Cyperus s. s. has about 550 species and is recognized by the presence of a rosette of leaves - formed as the result of a combination of the short internodes with the spirally alternate phyllotaxis, terminal inflorescence, distichous glumes, hermaphroditic flowers, trifid style, and trigonous achene (Goetghebeur 1998). In Brazil, there are registered about 100 species, which are found in varied habitats and vegetation types (Alves et al. 2014).

In the South Region of Brazil, Cyperus was extensively studied: Araújo \& Longhi-Wagner (1996) dealt with the flora of Cyperus subg. Anosporum in the state of Rio Grande do Sul; and Hefler \& Longhi-Wagner (2012) on Cyperus subg. Cyperus to the South Region.

In the Northeast Region, the most complete treatment was made by Luceño et al. (1997), which contains identification keys and taxonomic comments to species of Cyperaceae occurring in the states of Paraíba and Pernambuco (Cyperus represented by 31 species). Besides that Alves \& Martins (2009) included six species of Cyperus for local flora of Mirandiba (Pernambuco), as well as Costa (2013) with 22 species the state of Sergipe.

In the state of Rio Grande do Norte, Ribeiro et al. (2014) studied the flora of Cyperaceae related to the Apodi-Mossoró river, including 14 species of Cyperus with descriptions and identification key. The other works that include species of Cyperus occurring in the state are only lists (Almeida Júnior \& Zickel 2009; Henry-Silva et al. 2010; Oliveira et al. 2013).

The present work aims to provide a taxonomic study of the species of Cyperus occurring in the state of Rio Grande do Norte, northeastern Brazil. It includes, besides comments on the geographical distribution of the species and delimitation of taxa, descriptions, illustrations, and a key for the identification of the species.

\section{Material and Methods}

The study was based on an intensive program of collection from July 2006 to May 2010 throughout the state of the Rio Grande do Norte: 21 field expeditions along ApodiMossoró river (supported by the project Petrobrás Ambiental/rio Apodi-Mossoró), one expedition to the middle West and Seridó regions, one to the Low Açu valley, one to the Agreste Potiguar, and three to the East Littoral region. In addition, it was analyzed the specimen collections deposited in the herbaria EAC, HUEFS, MOSS, UB, UFRN and UFP (abbreviations according to Thiers [continuously updated]). The descriptions of the character states followed Radford et al. (1974).

The vegetation was classified according to IDEMA (2007) (Figure 1), in which the following types are recognized: Forests (Evergreen, Semideciduous, Deciduous, Riparian with Carnauba, and Floodplain), Secondary Formations (= Capoeiras), Caatingas (Hypoxerophilous, Hyperxerophilous, and Seridó), Cerrado, Campos (Floodplain, HumanImpacted, and Secondary), and other formations (Sandbanks, Mangroves, Rupicolous Formations, and Halophilous Formations in Saline Desert).

\section{Results and Discussion}

It was identified 24 species of Cyperus in the state of Rio Grande do Norte, including a new species (Cyperus sp. 1), here described, but that will be properly published elsewhere. This new species was found in vegetation of Caatinga and is morphologically similar to C. alvesii G.C. Tucker and $C$. ligularis $\mathrm{L}$, but can be recognized by the spikelets, glumes and rachilla internodes.

In this study, it is included also six new occurrences for the state of Rio Grande do Norte, not cited by Alves et al. (2014) and Ribeiro et al. (2014). The occurrence of Cyperus digitatus in the Northeast Region had been previously reported only to the states of Bahia, Maranhão and Pernambuco (Hefler \& Longhi-Wagner 2012; Alves et al. 2014), but analyzis of specimens in the herbaria EAC and UFRN revealed that this species has a wider distribution, which includes the states of Rio Grande do Norte and Ceará.

Araújo \& Longhi-Wagner (1996) treated C. entrerianus Boeckeler as a variety of $C$. luzulae (L.) Rottb. ex Retz. In the present study followed Alves et al. (2014), in which $C$. 
entrerianus and C. luzulae are treated as distinct species. As well as pointed out by Tucker (1994), allopatric distribution is confirmed for both, as well as morphological differences. Also, while C. entrerianus was found in the Caatinga and associated forest formations, C. luzulae was found in patches of Cerrado in eastern humid littoral.

Some species are widely distributed throughout the distinct vegetation formations of the Rio Grande do Norte State and were found in environments from Caatinga to more humid forest formations. Among the widely distributed species, there are C. aggregatus (Willd.) Endl., C. compressus L., C. odoratus L. and C. surinamensis Rottb. Despite the scant documentation in herbaria, C. rotundus $\mathrm{L}$. is also widely distributed in Rio Grande do Norte, but always in association with human activities.

In the state, other species are restricted to Caatinga as C. schomburgkianus Nees, $C$. uncinulatus Schrad. ex Nees and the Cyperus sp. 1 species. Luceño et al. (1997) also reported $C$. schomburgkianus and C. uncinulatus to Caatinga in the states of Paraíba e Pernambuco. According to Costa (2013), C. schomburgkianus occurs in a similar habitat, but $C$. uncinulatus occurs also in the Atlantic Forest, in the state of Sergipe.

Some species were found associated with either Cerrado or forest formations in the humid eastern littoral (Atlantic Forest) as well as in the inland portions of Rio Grande do Norte (relicts of Semideciduous, and Deciduous Forests situated at higher altitudes). Cyperus distans L. f. was always found associated with forestborder environments and C. haspan L. with Cerrado areas in Canguaretama-RN as well as with forest-border environments, in both the humid littoral and inland relicts of vegetation formations. Cyperus laxus Lam., although often occurring in ombrophilous environments under forest canopies, was also found in forest borders and Cerrado. Luceño et al. (1997) reported $C$. laxus to occur in ombrophilous environments associated with nitrified soils in the states of Paraíba and Pernambuco.

The species found exclusively occurring in Sandbanks, suggesting tolerance to coastal salinity, are $C$. crassipes Vahl, $C$. hermaphroditus (Jacq.) Standl., and C. sphacelatus Rottb. A similar distribution was observed in the states of Paraíba,
Pernambuco and Sergipe (Luceño et al. 1997; Hefler \& Longhi-Wagner 2012; Costa 2013). The geographical distribution of $C$. crassipes is even wider, including the semiarid coast of Rio Grande do Norte. According to Martins et al. (2008), C. crassipes (under the name C. maritimus Poir.) bears a combination of morpho-anatomical and physiological characters which provide resistance to xeric and saline environments. On the other hand, the geographical distribution of $C$. hermaphroditus and C. sphacelatus is restricted to the humid coastal areas. In the state of Rio Grande do Norte, there is an abrupt pluviometric transition delimiting two coastal strips: one semiarid adjacent to the Caatinga at the septentrional coast and the other humid adjacent to the Atlantic Forest at the eastern coast (IDEMA 2007) (Figure 1). This climatic pattern may explain the geographical distribution of $C$. hermaphroditus and C. sphacelatus, as well as Remirea maritima Aubl., suggesting a higher water requirement for these species.

Some species of Cyperus listed by CRIA (2014) need to be confirmed in the Rio Grande do Norte State. The specimen R.A. Pontes 779 (JPB) identified as C. atlanticus Hemsl. was not found at the cited herbarium as well as D.S.D. Araújo 7626 (NY) as C. laevigatus L., and Andrade-Lima 68-5387 \& 68-5389 (IPA) as C. planifolius Rich.

\section{Taxonomic Treatment}

Cyperus L., Sp. P1.: 44. 1753.

Herbs cespitose or rhizomatous. Rhizome absent or present. Culm simple, trigonous or cylindrical, glabrous, rarely scabrous. Leaves alternate, spirally arranged in a basal rosette. Leaf blade absent or present. Ligule absent, rarely present. Contraligule absent. Involucral bracts present. Inflorescence terminal, simple or compound, in 1-5 orders, as anthelodia, glomerules, spikes, subdigitate spikes, digitate clusters or fascicles. Bract of the spikelet present. Prophyll of the spikelet present. Spikelets 3-many per inflorescence, persistent or deciduous, basally subtended by an abaxial bract and an adaxial prophyll. Rachilla articulate or not, wings absent or present. Glumes 2-many, distichous, persistent or deciduous, 1-2-carinate, glabrous; carina rarely scabrous. Flowers hermaphroditic. Style trifid; stigmata 3. Stamina 1-3; anthers yellowish, with connective prolonged or not. Achene trigonous. Stylopodium absent. 
Dichotomous key for the identification of the species of Cyperus L. occurring in Rio Grande do Norte

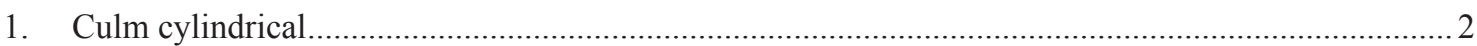

2. Transverse septa present in the culm; inflorescence with anthelodia in the $1^{\text {st }}$ order; glumes $2.5-3.8$ $\times 1-1.6 \mathrm{~mm}$

3. Cyperus articulatus

2'. Transverse septa absent in the culm; inflorescence with either glomerule or spike in the $1^{\text {st }}$ order; glumes 6-7.8 × 3.5-4.2 $\mathrm{mm}$.

5. Cyperus crassipes

1'. Culm trigonous

3. Culm retrorsely scabrous

22. Cyperus surinamensis

3'. Culm smooth or papillose, rarely antrorsely scabrous ............................................................ 4

4. Leaf blade chartaceous, glaucous.

5. Spikelets $3.5-8 \mathrm{~mm}$ long; rachilla internodes $0.4-0.8 \mathrm{~mm}$ long; glumes $2.2-2.6 \mathrm{~mm}$ long, 5-8 per spikelet

15. Cyperus ligularis

5'. Spikelets 6-14 mm long; rachilla internodes 0.9-1.2 mm long; glumes 2.7-3 mm long, (5)7-11 per spikelet 24. Cyperus sp. 1

4'. Leaf blade membranaceous, green

6. Rachilla articulate at the base and all nodes, spikelet splitting into diaspores composed of 1 glume, 1 achene and 1 rachilla internode; rachilla wings spongy and rigid, becoming marginally membranaceous.

17. Cyperus odoratus

6'. Rachilla non-articulate or articulate only at the base; spikelet persistent or falling as a 2-many-glumed unity; rachilla wings absent or completely membranaceous........... 7

7. Glumes brown with a vinaceous area near each margin, forming a longitudinal line along the center of each lateral side of the spikelet..........20. Cyperus sphacelatus

7'. Glumes homogeneously colored, not forming a vinaceous longitudinal line along the lateral sides of the spikelet

8. Glumes mucronate or aristate; mucron/arista longer than or equal to $0.3 \mathrm{~mm}$ long.....

9. Glumes wider than or equal to $1.6 \mathrm{~mm}$ wide; achene wider than or equal to $0.8 \mathrm{~mm}$ wide

10. Glumes $2.3-2.9 \mathrm{~mm}$ long; connective prolongation glabrous or absent at the anther apex; achene 1.1-1.2 $\mathrm{mm}$ long

4. Cyperus compressus

10 '. Glumes $1.2-1.5 \mathrm{~mm}$ long; connective prolongation with antrorse bristles; achene 1.3-1.6 $\mathrm{mm}$ long.... 14. Cyperus laxus

9'. Glumes narrower than or equal to $1 \mathrm{~mm}$ wide; achene narrower than or equal to $0.4 \mathrm{~mm}$ wide 11

11. Rachilla articulate at the base, spikelets falling as a unity; glumes persistent, medially 7-9-nervate.

21. Cyperus squarrosus

11'. Rachilla non-articulate, spikelets persistent; glumes deciduous, medially 3(5)-nervate

12. Herb $3.5-6.5 \mathrm{~cm}$ tall; rachilla internodes $0.3-0.5 \mathrm{~mm}$ long; androecium 3-staminate; anther $0.15-0.20 \mathrm{~mm}$ long

6. Cyperus cuspidatus

12'. Herb $6.5-29 \mathrm{~cm}$ tall; rachilla internodes $0.2-0.3 \mathrm{~mm}$ long; androecium 1-staminate; anther $0.4-0.6 \mathrm{~mm}$ long

23. Cyperus uncinulatus

8'. Glumes muticous or mucronate; mucron shorter than or equal to $0.2 \mathrm{~mm}$ long

13. Rachilla articulate at the base, spikelets falling as a unity

14. Glumes 2-3.2 mm long; anther 0.4-0.7 mm long; achene 1.5-2 mm long. 1. Cyperus aggregatus

14'. Glumes 3.9-4.9 mm long; anther 0.7-1.3 mm long; achene 2.3-3 mm long. 12. Cyperus hermaphroditus

13'. Rachilla non-articulate; spikelets persistent 
15. Glumes medially bicarinate

16. Spikelets in serial fascicles at the ultimate order of the inflorescence; rachis $0.3-0.5 \mathrm{~mm}$ long; achene $0.6-0.8 \mathrm{~mm}$ long 22. Cyperus surinamensis

16'. Spikelets in glomerules or in spikes at the ultimate order of the inflorescence; rachis longer than $1 \mathrm{~mm}$; achene $0.8-1 \mathrm{~mm}$ long.....

17. Spikelets in spherical to hemispherical glomerules at the ultimate order of the inflorescence; rachis shorter than $3 \mathrm{~mm}$; glumes green, becoming brown when dehydrating; anther 0.6-0.9 mm long

9. Cyperus entrerianus

17'. Spikelets in spikes at the ultimate order of the inflorescence; rachis longer than $3.5 \mathrm{~mm}$; glumes white becoming brown when dried; anther 0.4-0.5 $\mathrm{mm}$ long...

16. Cyperus luzulae

15'. Glumes unicarinate 18

18. Inflorescence glomerule (spherical to hemispherical) forming a single order; glumes with margins and carina white, becoming to brown when dried ..... 19. Cyperus schomburgkianus

18'. Inflorescence with 2 or more orders, but with anthelodia in the first order; glumes maroon, vinaceous, ferruginous, yellowish or brown at the margins and green to brown at the carina.

19. Glumes persistent on the rachilla; anther $1.1-1.8 \mathrm{~mm}$ long

20. Rachilla internodes $0.6-0.8 \mathrm{~mm}$ long; glumes brown to ochraceous

20'. Rachilla internodes $0.9-1.4 \mathrm{~mm}$ long; glumes vinaceous. 10. Cyperus esculentus 19'. Glumes deciduous; anther 0.3-0.6(0.7) $\mathrm{mm}$ long... 18. Cyperus rotundus

21. Spikelets in digitate group or rarely subdigitate spike at the ultimate order of the inflorescence, rachis $0.2-1.0 \mathrm{~mm}$ long; achene $0.4-0.7 \mathrm{~mm}$ long.... .22

22. Culm 0.4-0.7(1.5) $\mathrm{mm}$ wide; bracts of $1^{\text {st }}$ order 3-9; androecium 1-staminate.......

2. Cyperus amabilis

22'. Culm 1.2-6 mm wide; bracts of $1^{\text {st }}$ order 2-3; androecium 3-staminate

11. Cyperus haspan

$21^{\prime}$. Spikelets in spike at the ultimate order of the inflorescence, rachis $1.2-55 \mathrm{~mm}$ long; achene $0.9-1.5 \mathrm{~mm}$ long.....

23. Glumes $2.4-2.8 \mathrm{~mm}$ long; rachilla wings $0.3-0.4 \mathrm{~mm}$ wide; achene $0.6-0.7 \mathrm{~mm}$ wide

20. Cyperus sphacelatus

23'. Glumes $1.2-2.2 \mathrm{~mm}$ long; rachilla wings absent or up to $0.3 \mathrm{~mm}$ wide; achene $0.4-0.6 \mathrm{~mm}$ wide 24

24. Rachilla internodes $0.8-1.1 \mathrm{~mm}$; glumes maroon-vinaceous to brown; achene $1.4-1.5 \mathrm{~mm}$ long.... 8. Cyperus distans

24'. Rachilla internodes $0.3-0.7 \mathrm{~mm}$; glumes yellow to yellowish-brown; achene $0.9-1.2 \mathrm{~mm}$ long. 25

25. Rachilla wings yellow, $0.2-0.3 \mathrm{~mm}$ wide; glumes $0.6-1 \mathrm{~mm}$ wide, medially 7-9-nervate, without a hyaline marginal stripe at the apex......

7. Cyperus digitatus

$25^{\prime}$. Rachilla wings absent or hyaline to vinaceous up to $0.1 \mathrm{~mm}$ wide; glumes $1.4-1.8 \mathrm{~mm}$ wide, medially $3-5$-nervate, with a hyaline marginal stripe at the apex. 13. Cyperus iria

1. Cyperus aggregatus (Willd.) Endl., Cat. Horti Vindob. 1: 93. 1842.

Fig. 2a

Herb cespitose, $15.5-65 \mathrm{~cm}$ tall. Culm $135-620 \times 1.3-2.8 \mathrm{~mm}$, trigonous, transverse septa absent, glabrous, smooth. Leaf blade membranaceous, green. Bracts of $1^{\text {st }}$ order $4-10$, 20-290 × 0.8-7 mm. Inflorescence 1.8-2.6 $\times$
$2.2-6.2 \mathrm{~cm}$, in 2 orders: hemispherical glomerule in the $1^{\text {st }}$ order, spike in the ultimate order. Rachis 4-20 mm long, apparent or hidden by spikelets. Spikelets $2.1-4.6 \times 0.9-1.5 \mathrm{~mm}, 0.6-1.1 \mathrm{~mm}$ thick. Rachilla articulate at the base, spikelet falling as a unity, internodes $1.1-1.6 \mathrm{~mm}$ long. Rachilla wings present, $0.6-1.3 \mathrm{~mm}$ wide, 
membranaceous, hyaline or greenish-hyaline, sometimes with vinaceous areas. Glumes 2-3, 2-3.2 × 1.6-2.5 mm, persistent, unicarinate, medially 9-13-nervate (including carina), brown, greenish-brown to yellowish-brown, sometimes with vinaceous-maculated margins, green at the carina, glabrous, muticous to rarely mucronate; mucron straight, up to $0.2 \mathrm{~mm}$ long. Stamina 3 ; anther $0.4-0.7 \times 0.15-0.2 \mathrm{~mm}$; connective prolongation absent or present at the anther apex, up to $0.1 \mathrm{~mm}$ long, hyaline, reddish to vinaceous, glabrous. Achene $1.5-2 \times 0.6-1 \mathrm{~mm}, 0.6-1 \mathrm{~mm}$ thick, obovoid, sometimes ellipsoid or oblong, rarely ovoid, mucron $0.1 \mathrm{~mm}$ long.

Material examined selected: Campo Grande, 2.VI.2007, fl. e fr., A.M. Marinho \& A.L.M. Marinho 44 (MOSS); Grossos, Salina Salmar, 28.VI.2007, fl. e fr., A.A. Roque 189 (UFRN); Luís Gomes, estrada para Tigre de Cima, margem de afluente do Rio ApodiMossoró, próximo a ponte da Baixa do Almeida, 6 $233^{\prime} 53^{\prime}$ ' S, 38 $24^{\prime} 36^{\prime \prime}$ W, 30.V.2008, fl. e fr., A.R.O. Ribeiro et al. 175 (MOSS); Martins, Açude Portinho, 605'38' S, 37055'57' W, 25.IV.2006, fl. e fr., M.I.B. Loiola 871 (MOSS, UFRN); Mossoró, 511'31" S, $37^{\circ} 20$ '40" W, 11.V.1980, fl. e fr., O.F. Oliveira et al. 855 (MOSS); Parnamirim, EMPARN, 17.II.2006, fl. e fr., R.T. Queiroz \& M.Z. Cardoso 596 (MOSS); Passa e Fica, na saída para Nova Cruz, 6026’32" S, 35०37'70" W, 14.V.2009, fl. e fr., R.C. Oliveira et al. 2397 (MOSS); Santo Antônio, 1 km após o povoado de Lagoa Limpa, em direção a Santo Antônio, 6 ${ }^{\circ} 25^{\prime} 47^{\prime}$ " S, 3526'84" W, 14.V.2009, fl. e fr., R.C. Oliveira et al. 2417 (MOSS); São Paulo do Potengi, 4 km após o trevo Riachuelo-São Paulo do Potengi, 5 52'42" S, $35^{\circ} 45^{\prime} 77^{\prime}$ ' W, 14.V.2009, fl. e fr., R.C. Oliveira et al. 2370 (MOSS); Serrinha dos Pintos, Serrinha do Canto, próximo à casa de Rubens, 17.IV.2005, fl. e fr., R.T. Queiroz \& F.R. Queiroz 153 (MOSS, UFRN).

Geographical distribution and phenology: Widely distributed: Atlantic Forest (Evergreen), Inland Forests in higher altitudes (Semideciduous and Deciduous), Riparian Forest with Carnauba, Caatingas (Hypoxerophilous and Hyperxerophilous), Sandbanks, and Saline Desert. Flowers and fruits: February, April-July.

Comments: recognized by the spherical to hemispherical glomerule of spikes of spikelets, densiflorous spikes, and spikelets greenish to yellowish with 2-3 glumes.

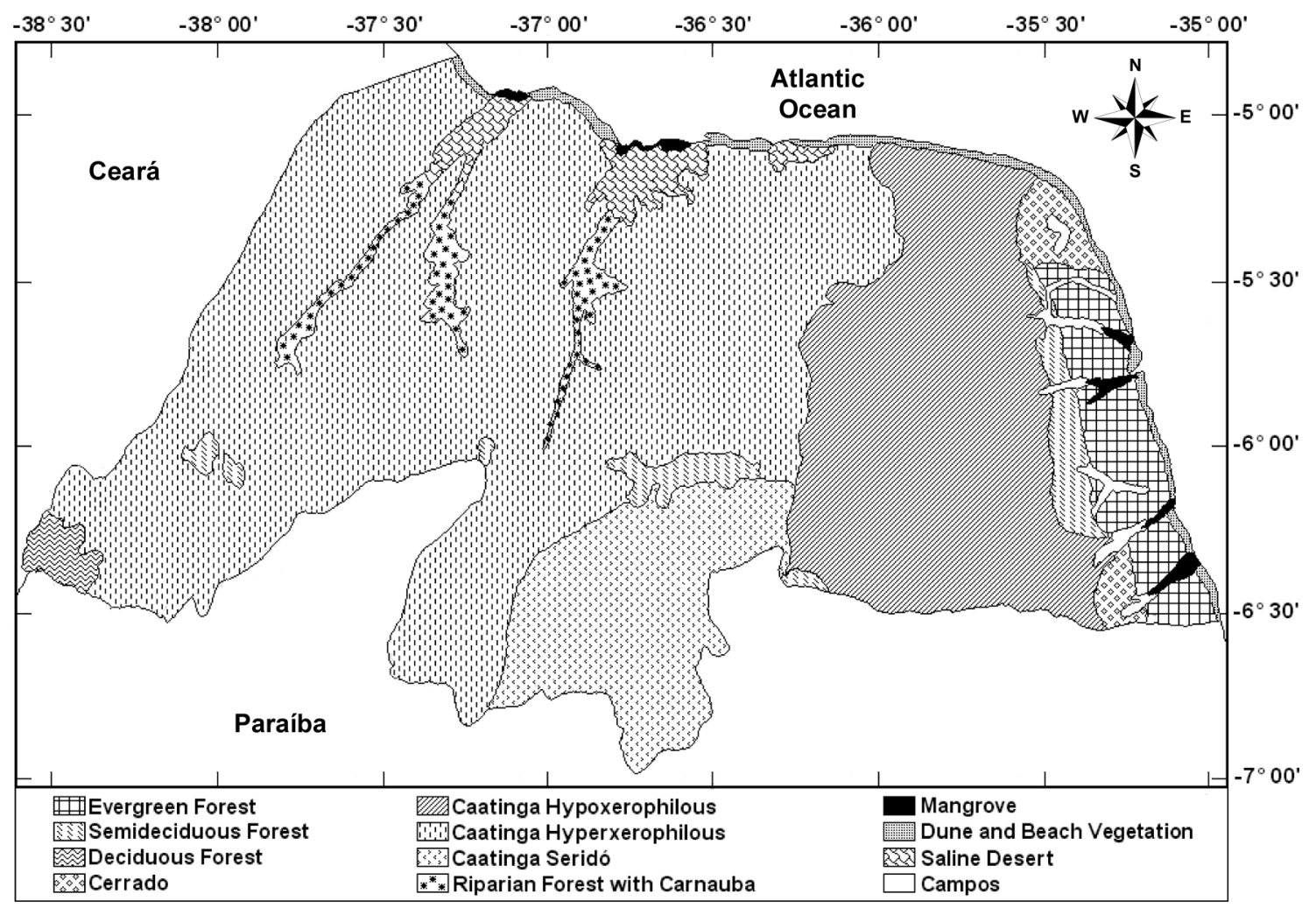

Figure 1 - Approximate distribution of vegetation types in the state of Rio Grande do Norte (adapted from IDEMA 2007). 

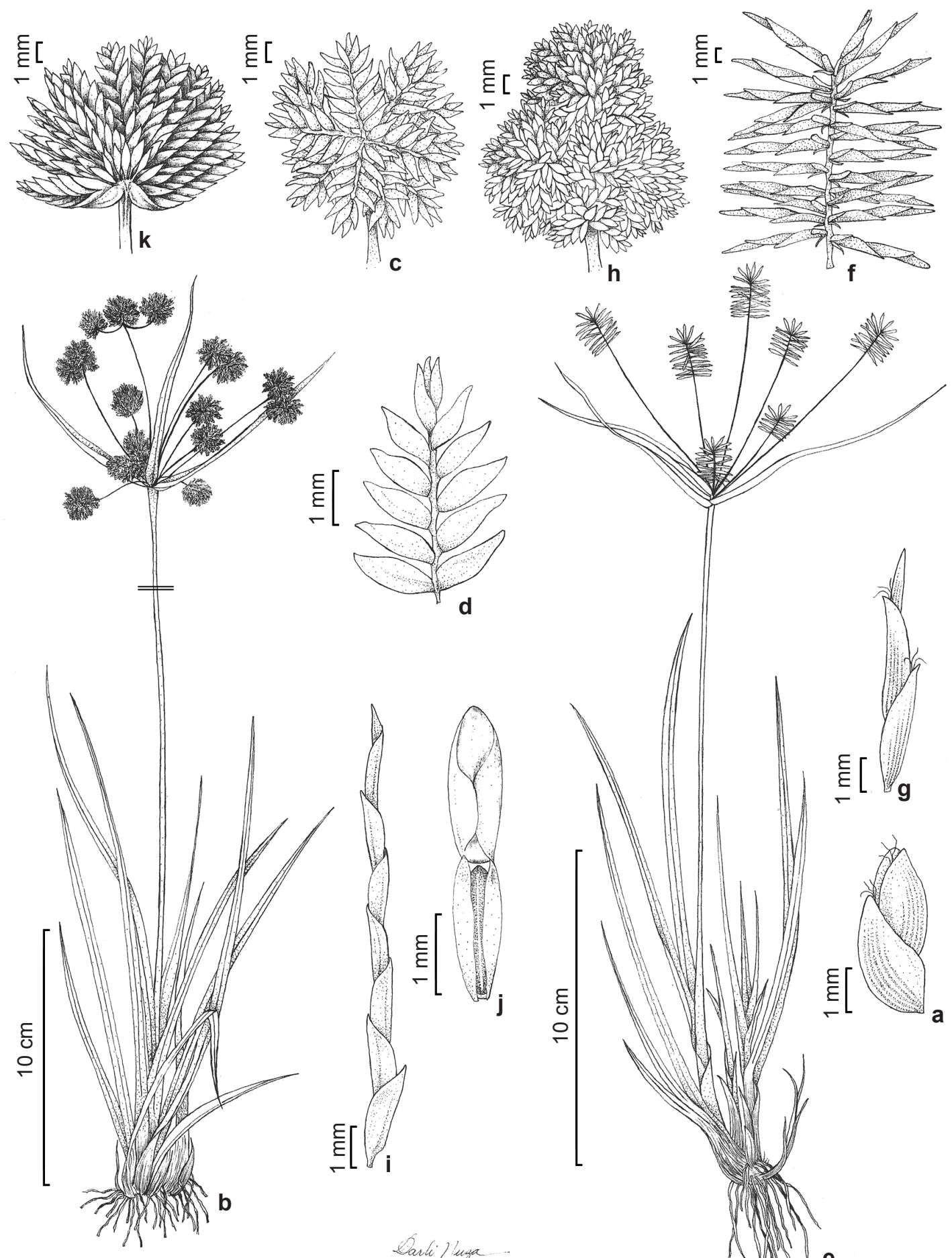

翠章
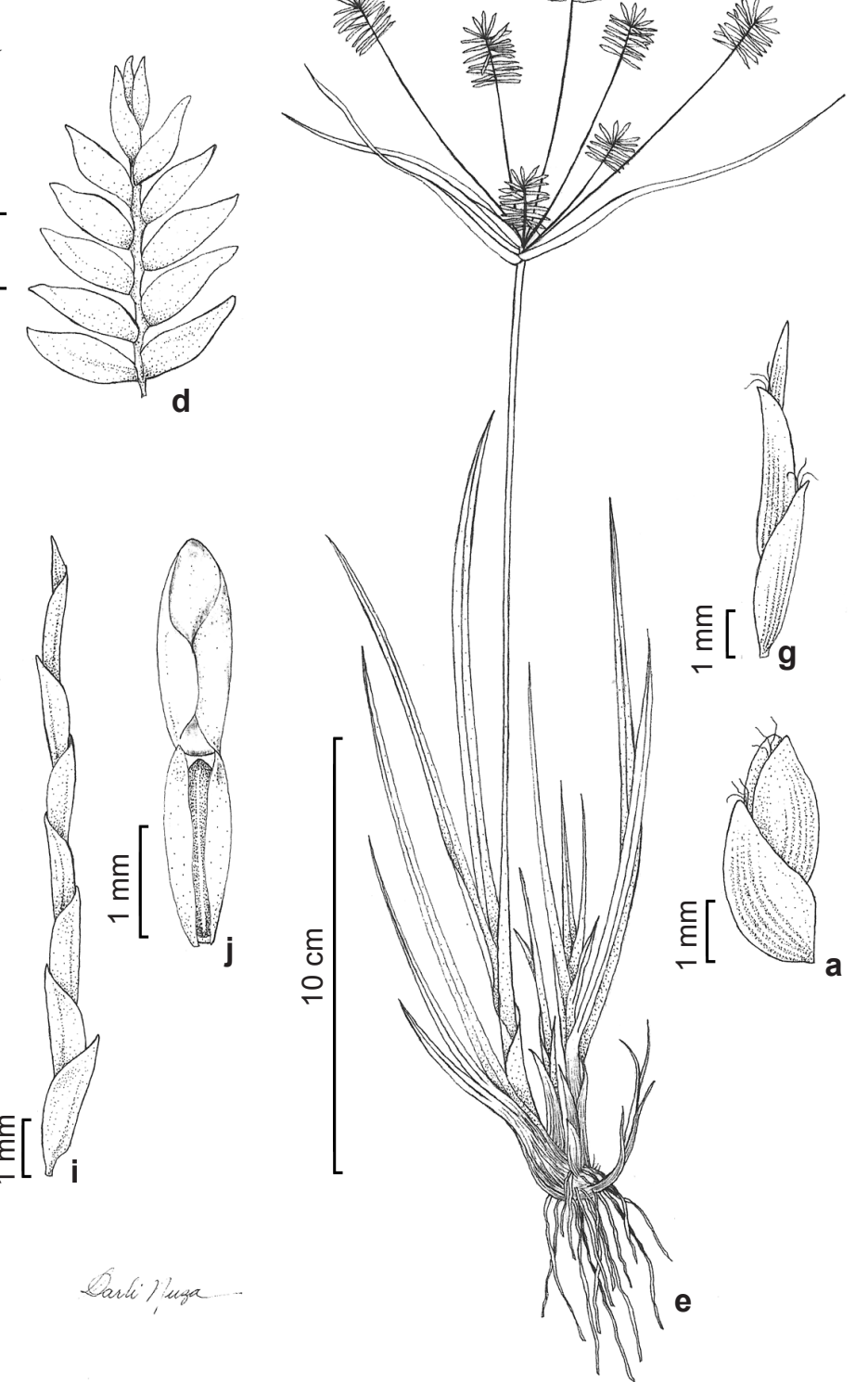

Figure 2 - a. Cyperus aggregatus - spikelet. b-d. C. entrerianus - b. habit; c. glomerule; d. spikelet. e-g. C. hermaphroditus - e. habit; f. spike; g. spikelet. h. C. luzulae - spike. i-j. C. odoratus - i. spikelet; j. diaspore: glume above, rachilla segment involving achene below. k. C. surinamensis - serial fascicle (a A.R.O. Ribeiro et al. 175; b-d A.R.O. Ribeiro et al. 151; e-g M. Araújo Junior s.n. (MOSS 5569); h A.R.O. Ribeiro et al. 49; i-j A.R.O. Ribeiro 82; kA.R.O. Ribeiro 157). 
2. Cyperus amabilis Vahl, Enum. Pl. 2: 318. 1805.

Fig. 3a

Herb cespitose 11.5-22(30) cm tall. Culm 55-185 $\times 0.4-0.7(1.5) \mathrm{mm}$, trigonous, transverse septa absent, glabrous, smooth. Leaf blade present, membranaceous, green. Bracts of $1^{\text {st }}$ order 3-9, 5-43 $\times 0.5-2 \mathrm{~mm}$. Inflorescence 3.8-8.5(12) $\times$ $2.6-12(23) \mathrm{cm}$, in $2-3$ orders; antelodium in the $1^{\text {st }}$ order; antelodium or digitate group, rarely spike subdigitate in the $2^{\text {nd }}$ order; digitate group or rarely subdigitate spike in the ultimate order. Rachis $0.2-0.8 \mathrm{~mm}$ long, apparent. Spikelets 6-9(19) $\times 1.1-1.4(3) \mathrm{mm}, 0.3 \mathrm{~mm}$ thick. Rachilla non-articulate, spikelet persistent, internodes $0.3-0.5 \mathrm{~mm}$ long. Rachilla wings absent or present, up to $0.1 \mathrm{~mm}$ wide, membranaceous, hyaline. Glumes 9-22(34), 1.2-1.6 ×0.8-1 mm, deciduous, unicarinate, medially 3 -nervate (including carina), maroon-vinaceous to maroon-ferruginous at the margins, green at the carina, glabrous, mucronate; mucron $0.1-0.2 \mathrm{~mm}$, straight to slightly recurvate up to a $20^{\circ}$ angle. Stamen 1; anther $0.3 \times 0.1$ $\mathrm{mm}$; connective prolongation absent or present at the anther apex, up to $0.1 \mathrm{~mm}$ long, reddish to vinaceous, glabrous. Achene $0.5-0.7 \times 0.3-0.4$ $\mathrm{mm}, 0.3-0.4 \mathrm{~mm}$ thick, obovoid, with a mucron $0.1 \mathrm{~mm}$ long.

Material examined: Apodi, 5039'50" S, 37047'56" W, 27.IV.1980, fl. e fr., O.F. Oliveira et al. 538 (MOSS); Areia Branca, 4⒌'22” S, 3708'13” W, 11.VI.1995, fl. e fr., M. José et al. (MOSS 5356); Grossos, Salina Salmar, A.A. Roque 277 (UFRN); Jandaíra, 5०21'23”'S, $37^{\circ} 07^{\prime} 41$ ” W, 13.V.1986, fl. e fr., S.H. Vasconcelos 19 (MOSS); Mossoró, coletada no distrito de Alagoinha, fazenda Experimental Rafael Fernandes, 5 ${ }^{\circ} 03^{\prime} 06^{\prime}$ " S, 37²3'45" W, 17.V.2007, fl. e fr., M.L. Silva 265 (MOSS); Tibau do Sul, Praia de Pipa, 4.VIII.1995, fl. e fr., M. Luceño 354 (UFP); Tibau do Sul, 6¹6'15" S, 35'02'18" W, 15.VII.2006, fl. e fr., R.C. Oliveira et al. 1728 (MOSS); Touros, 5'11'56" S, 35'27'39" W, 29.V.1997, fl. e fr., P.A.R. Lopes et al. 26 (MOSS).

Geographical distribution and phenology: restricted to Caatingas (Hypoxerophilous, Hyperxerophilous, and Seridó), Sandbanks, and Saline Desert. Flowers and fruits: April-August.

Comments: At first sight, $C$. amabilis may be confused with $C$. haspan, since its spikelets are reddish to maroon and have a short, straight to slightly recurvate arista. However, C. amabilis has 3-9 $1^{\text {st }}$ order bracts, the androecium is 1 -staminate and the achene is maroon to maroon-ferruginous to brown, whereas in $C$. haspan there are $2-31^{\text {st }}$ order bracts, the androecium is 3 -staminate, and the achene color varies from white to beige.
3. Cyperus articulatus L., Sp. Pl.: 44. 1753.

Fig. $4 a-b$

Herbs rhizomatous $63-181.5 \mathrm{~cm}$ tall. Culm 570-1750 × 2.8-10 mm, cylindrical, transverse septa present, glabrous, smooth. Leaf blade absent, rarely present, membranaceous, green. Bracts of $1^{\text {st }}$ order 3-6, 4-23 $\times 0.4-6 \mathrm{~mm}$. Inflorescence $2.5-15 \times 2-10 \mathrm{~cm}$, in $2-3$ orders: antelodium in the $1^{\text {st }}$ order; antelodium or spike in the $2^{\text {nd }}$ order; spike in the ultimate order. Rachis 2-3 $\mathrm{mm}$ long, apparent. Spikelets (5)9-40 × 1.1-1.4 $\mathrm{mm}, 0.4-0.7 \mathrm{~mm}$ thick. Rachilla non-articulate, spikelet persistent, internodes $0.7-1.2 \mathrm{~mm}$ long. Rachilla wings present, $0.2-0.5 \mathrm{~mm}$ wide, membranaceous, hyaline, sometimes vinaceousmaculate. Glumes (5)12-33, 2.5-3.8 × 1-1.6 mm, deciduous, unicarinate, medially 5-11-nervate (including carina), brown, yellowish-brown or brown-vinaceous at the margins, green at the carina, glabrous, muticous, rarely mucronate, mucron up to $0.1 \mathrm{~mm}$ long, straight. Stamina 3; anther 1.2-2 $\times 0.15-0.3 \mathrm{~mm}$; connective prolongation absent or present at the anther apex, up to $0.1 \mathrm{~mm}$ long, reddish to vinaceous, glabrous. Achene 1.1-1.4 $\times$ $0.4-0.7 \mathrm{~mm}, 0.4-0.5 \mathrm{~mm}$ thick, oblong-obovoid to oblanceoloid, with a mucron $0.1 \mathrm{~mm}$ long.

Material examined selected: Açu, 5⒊' $\mathrm{S}, 36^{\circ} 54^{\prime} \mathrm{W}$, 5.III.1993, fl. e fr., R.A. Sousa 3 (MOSS); Apodi, Lagoa

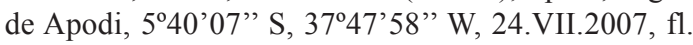
e fr., G.H.G. Silva et al. 14 (MOSS); Augusto Severo, Fazenda Boa Vista, 5'55' S, 37²0'50" W, 8.IV.1980, fl. e fr., O.F. Oliveira et al. 954 (MOSS); Caicó, Comunidade Rural de Laginhas, 8.I.2008, fl. e fr., A.A. Roque 382 (UFRN); Grossos, Bairro Coqueiros, $4^{\circ} 58^{\prime} 48^{\prime \prime}$ S, 3709'18" W, 4.V.2006, fl. e fr., C.G.T. Ferreira \& S.V.O. Silva 97 (EAC, MOSS); Jardim do Seridó, margens do Rio Seridó, próximo à ponte de Zé de Bastos, 15.III.2009, fl. e fr., A.A. Roque 699 (UFRN); Mossoró, caminho para Areia Branca, em frente à Fazenda Sussuarana, 5०11'15" S, 37'20'39" W, 17.III.2007, fl. e fr., R.C. Oliveira et al. 1840 (EAC, MOSS); Natal, Lagoa do Guamoré, 5'42'37" S, 35 $15^{\prime} 44^{\prime}$ ' W, 4.XI.2007, fl. e fr., A.R.O. Ribeiro et al. 64 (EAC, MOSS); Passa e Fica, na saída para Nova Cruz, 6²6’32" S, 35³7'70" W, 14.V.2009, fl. e fr., R.C. Oliveira et al. 2395 (MOSS); Tibau do Sul, Distrito de Pipa, 29.V.2006, fl. e fr., S. Martins \& M. Alves 231 (UFP).

Geographical distribution and phenology: Widely distributed: border of the Atlantic Forest (Evergreen), Riparian Forest with Carnauba, Caatingas (Hypoxerophilous, Hyperxerophilous, and Seridó), Sandbanks, and Saline Desert. Flowers and fruits along the year. 

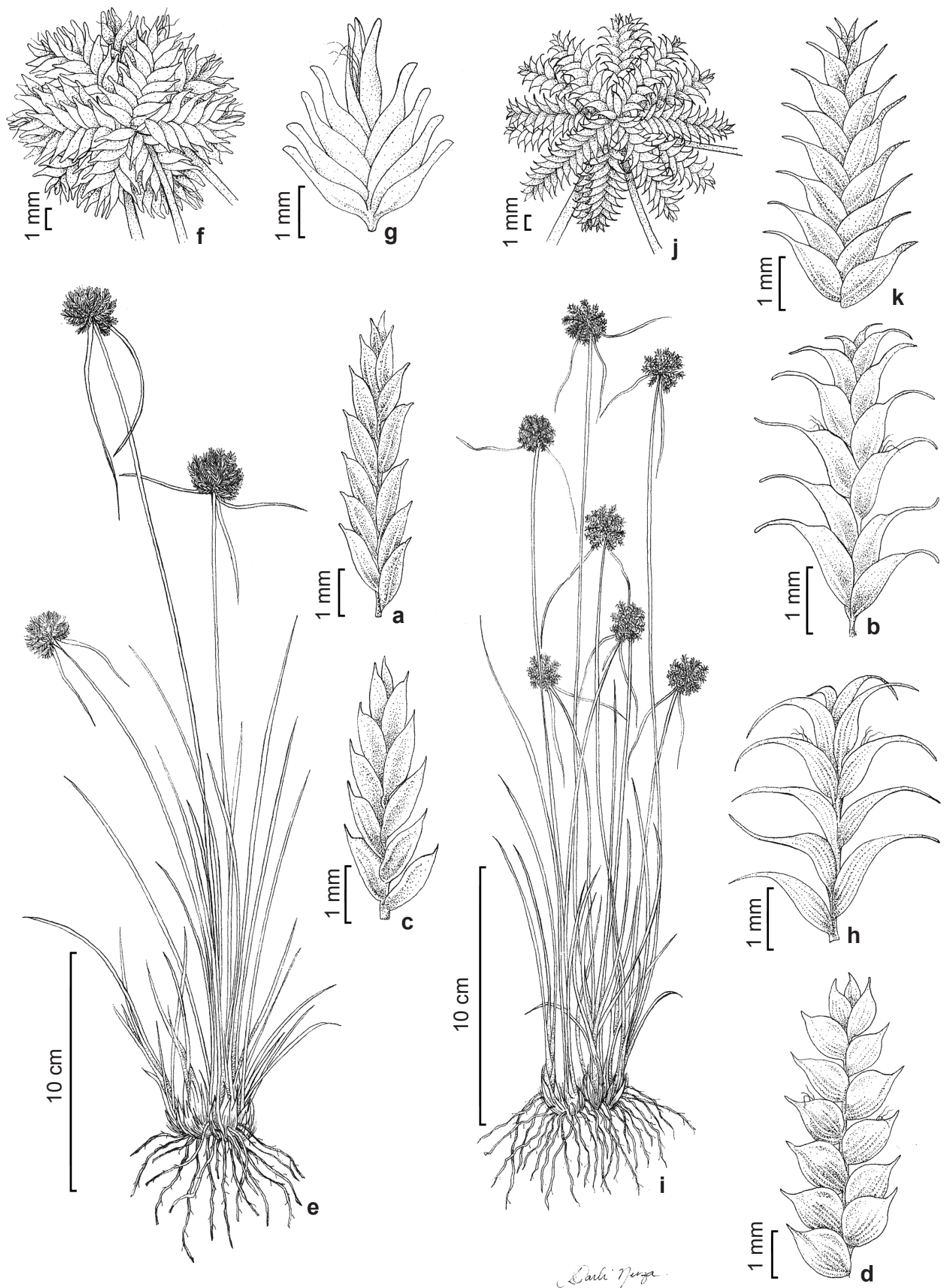

Figure 3 - a. Cyperus amabilis - spikelet. b. C. cuspidatus - spikelet. c. C. haspan - spikelet. d. C. laxus - spikelet. e-g. C. schomburgkianus - e. habit; f. glomerule; g. spikelet. h. C. squarrosus - spikelet. i-k. C. uncinulatus - i. habit; j. glomerule; k. spikelet (a R.C. Oliveira et al. 1728; b A.R.O. Ribeiro et al. 199; c A.R.O. Ribeiro et al. 30; d A.R.O. Ribeiro et al. 206; e-g R.C. Oliveira \& C.G.T. Ferreira 1645; h R.C. Oliveira et al. 2369; i-k R.C. Oliveira et al. 1921). 
Comments: recognized by the culm cylindrical and segmented by transverse septa, which become visible after being dried. In R.C. Oliveira et al. 1840, the leaf blade is present, a variation quite unusual in $C$. articulatus among studied specimens. This blade-bearing form is typical of the Cyperus articulatus var. nodosus (Humb. \& Bonpl. ex Willd.) Kük., according Adams (1994) and Kükenthal (1936).

Sometimes the $1^{\text {st }}$ order rays are very short, as in R.C. Oliveira et al. 1840 (EAC, MOSS), giving a compact aspect to the inflorescence. Among all specimens analyzed, presence of tuber $(25 \times 18$ $\mathrm{mm}$ ) was seen only in A.A. Roque 382 . The tubers and rhizomes produce an essence, commercially known as priprioca or piri-piri, which is used in the perfume industry. In the municipality of Mossoró$\mathrm{RN}$, the culms with inflorescence are of importance for composing floral arrangements.

\section{Cyperus compressus L., Sp. Pl.: 46. 1753.}

Fig. $4 \mathrm{c}$

Herb cespitose 14-47 cm tall. Culm 40-370 $\times 0.6-2 \mathrm{~mm}$, trigonous, transverse septa absent, glabrous, smooth. Leaf blade present, membranaceous, green. Bracts of $1^{\text {st }}$ order 3-7, 10-230 $\times 0.2-3 \mathrm{~mm}$. Inflorescence $0.8-8.5(11) \times 0.6-10.5(16) \mathrm{cm}$, in $1-2$ orders: antelodium, digitate group or subdigitate spike in the $1^{\text {st }}$ order; digitate group or subdigitate spike in the ultimate order. Rachis 1.8-3.5 mm long, apparent. Spikelets 7-19 × 2-3.1 mm, 0.8-1 mm thick. Rachilla non-articulate, spikelet persistent, internodes $0.6-1$ $\mathrm{mm}$ long. Rachilla wings absent or present, up to 0.2 $\mathrm{mm}$ wide, membranaceous, hyaline to ferruginous. Glumes 9-28, 2.3-2.9 × 1.6-2 mm, deciduous, unicarinate, medially 9-17-nervate (including carina), yellowish-glaucous or brown at the margins, green to brown at the carina, glabrous, mucronate or aristate; mucron/arista 0.4-0.9 mm long, straight, sometimes slightly recurvate (angle up to $20^{\circ}$ ). Stamina 3 ; anther $0.4-0.7 \times 0.1-0.15 \mathrm{~mm}$; connective prolongation absent or present at the anther apex, up to $0.1 \mathrm{~mm}$ long, hyaline, reddish to vinaceous, glabrous. Achene $1.1-1.2 \times 0.9-1 \mathrm{~mm}, 0.8-0.9 \mathrm{~mm}$ thick, largely obovoid, with a mucron $0.1 \mathrm{~mm}$ long.

Material examined selected: Apodi, Vazante da Barragem de Santa Cruz, próximo a área de recreação, 5.IV.2008, fl. e fr., R.C. Oliveira et al. 2110 (MOSS); Areia Branca, Salina Augusto Severo, 11.V.2007, fl. e fr., A.A. Roque \& A.C.P. Oliveira 47 (MOSS); Grossos, Salina Salmar, 28.VI.2007, fl. e fr., A.A. Roque 210 (UFP, UFRN); Luís Gomes, estrada para Cachoeira do Rela, próximo ao cumaru com Tillandsia, margem de afluente do
Rio Apodi-Mossoró, 6²3'51" S, 38²2'52"W, 31.V.2008, fl. e fr., A.R.O. Ribeiro et al. 210 (MOSS); Luís Gomes, Tigre de Cima, nascente do Rio Apodi-Mossoró, 6²1'26" S, $38^{\circ} 27^{\prime} 42$ " W, 30.V.2008, fl. e fr., A.R.O. Ribeiro et al. 205 (MOSS); Mossoró, margem de lago próximo à Feira do Bode, próximo ao Rio Apodi-Mossoró, 5¹1'58' S, 37¹9'31" W, 29.I.2008, fl. e fr., A.R.O. Ribeiro 102 (EAC, MOSS); Natal, Genipabu, 3.VIII.1994, fl. e fr., $M$. Luceño 210 (UFP); Passa e Fica, na saída para Nova Cruz, 6'26'32" S, 35037'70"'W, 14.V.2009, fl. e fr., R.C. Oliveira et al. 2398 (MOSS); Santo Antônio, $1 \mathrm{~km}$ após o povoado de Lagoa Limpa, em direção a Santo Antônio, 6²5'47"' S, 35²6'84" W, 14.V.2009, fl. e fr., R.C. Oliveira et al. 2402 (MOSS); Tibau do Sul, Distrito de Pipa, 29.V.2006, fl. e fr., S. Martins \& M. Alves 229 (UFP).

Geographical distribution and phenology: Widely distributed: Atlantic Forest (Evergreen), Inland Forests in higher altitudes (Semideciduous and Deciduous), Riparian Forest with Carnauba, Caatingas (Hypoxerophilous and Hyperxerophilous), Sandbanks, and Saline Desert. Flowers and fruits: January-June, August, and November.

Comments: recognized by the green spikelets arranged in either digitate groups or subdigitate spikes, with glumes 2.3-2.9 × 1.6-2 $\mathrm{mm}$, mucronate or aristate, the mucron/arista straight, rarely recurvate up to a $20^{\circ}$ angle.

\section{Cyperus crassipes Vahl, Enum. Pl. 2: 299.} 1805.

Fig. $4 d-f$

Herb cespitose $7.5-59 \mathrm{~cm}$ tall. Culm 60-540 $\times 1.2-4.8 \mathrm{~mm}$, cylindrical, transverse septa absent, glabrous, smooth. Leaf blade present, chartaceous, glaucous. Bracts of $1^{\text {st }}$ order $3-8,10-230 \times 1-8$ $\mathrm{mm}$. Inflorescence $1.8-6.5 \times 2.9-6.5 \mathrm{~cm}$, in $1-2$ orders: glomerule spherical to hemispherical or spike in the $1^{\text {st }}$ order; spike in the ultimate order. Rachis 3-7 mm long, hidden by spikelets or rarely apparent. Spikelets 8-28 × 2.5-6 mm, 2-2.5 mm thick. Rachilla articulate at the base, spikelet falling after abscission of the basal glumes, internodes $0.6-1.2 \mathrm{~mm}$ long. Rachilla wings absent or rarely present, $0.1 \mathrm{~mm}$ wide, membranaceous, hyaline to brown. Glumes $6-30,6-7.8 \times 3.5-4.2 \mathrm{~mm}$, deciduous, unicarinate, medially 11-19-nervate (including carina), brown, becoming gradually hyaline toward the margins, brown at the carina, glabrous, mucronate or aristate; mucron/arista $0.1-$ $0.4 \mathrm{~mm}$ long, straight. Stamina 3; anther 1.2-1.8 $\times 0.15-0.2 \mathrm{~mm}$; connective prolongation absent or present at the anther apex, $0.1-0.2 \mathrm{~mm}$ long, reddish to vinaceous, glabrous. Achene 2.1-2.5 $\times 0.9-1.2$ $\mathrm{mm}, 0.4-0.5 \mathrm{~mm}$ thick, obovoid to oblong-obovoid, with a mucron $0.1-0.2 \mathrm{~mm}$ long. 
Material examined selected: Areia Branca, 12.XII.1979, fl. e fr., M.R. Vodicka \& O.F. Oliveira 73 (MOSS); Extremoz, APA Jenipabu, área de entorno do Ecoposto, 5'42'03" S, 35¹2'27” W, 5.III.2010, fl. e fr., J.G. Jardim \& M.G. Ganade 5597 (UFRN); Guamaré, Mangue Seco, RDS Estadual Ponta do Tubarão, 1.VII.2008, fl. e fr., J.L.C. Lima 40 (UFRN); Macau, 18.VI.2005, fl. e fr., R.C. Oliveira 1581 (MOSS); Maxaranguape, 12.V.1993, fl. e fr., F.L. Gurgel 4 (MOSS); Natal, IBAMA, Parque das Dunas, 6.XI.1996, fl. e fr., A.P. Mendes \& A.C. Settini 399 (UFP); Nísia Floresta, Dunas da Praia de Búzios, 24.IV.2008, fl. e fr., A.M. Marinho 63 (MOSS); Tibau, dunas da Praia de Emanoelas, 17.V.2009, fl. e fr., R.C. Oliveira 2481 (MOSS); Tibau do Sul, Praia de Pipa, 12.X.2006, fl. e fr., M. Alves \& S. Heald (UFP 44400); Touros, Estrada de barro, Praia de Perobas em direção a Touros, em frente à Pousada e Restaurante Sinos do Vento, 5'13'32" S, 35²5'06" W, 19.V.2007, fl. e fr., M.I.B. Loiola \& M.A. Loiola 973 (UFRN, MOSS).

Geographical distribution and phenology: restricted to the Sandbanks including the humid eastern and semiarid northern coasts. Flowers and fruits: February-December.

Comments: recognized by the culm cylindrical; spikelets disposed in a dense spherical to hemispherical glomerule or globose spike at the apex of the culm, and glumes 6-7.8 $\times 3.5-4.2 \mathrm{~mm}$. In $C$. crassipes, the rhizome is narrow and long, horizontal and often covered by fibers, which makes it difficult to observe the nodes and internodes.

The inflorescence appears frequently to have only 1 branching order, because of its large number of spikelets hiding the rachis. Despite this, after the abscission of the basal glumes, it is possible to certify the presence of 2 branching orders in the inflorescence, as seen in R.C. Oliveira 1581 and M.I.B. Loiola \& M.A. Loiola 973, forming a glomerule of spikes of spikelets, and not merely a glomerule of spikelets. According to Martins et al. (2007), C. crassipes (under the name $C$. maritimus) combines a set of morpho-anatomical and physiological characteristics that confers resistance to both xeric and saline environments.

6. Cyperus cuspidatus Kunth, F. W. H. von Humboldt, A. J. A. Bonpland \& C. S. Kunth, Nov. Gen. Sp. 1: 204. $1817 . \quad$ Fig. 3b

Herb cespitose $3.5-6.5 \mathrm{~cm}$ tall. Culm 15$35 \times 0.3-0.5 \mathrm{~mm}$, trigonous, transverse septa absent, glabrous, smooth. Leaf blade present, membranaceous, green. Bracts of the $1^{\text {st }}$ order $3,4-27 \times 0.4-1.2 \mathrm{~mm}$. Inflorescence 0.8-1.9 $\times$ $1.2-1.9 \mathrm{~cm}$, in a single order: glomerule spherical to hemispherical or spike. Rachis $0.2-1.5(2) \mathrm{mm}$ long, apparent. Spikelets 4.9-9 × 1.1-1.5 mm, 0.3-0.4 mm thick. Rachilla non-articulate, spikelet persistent, internodes $0.3-0.5 \mathrm{~mm}$ long. Rachilla wings absent or present, $0.1-0.2 \mathrm{~mm}$ wide, membranaceous, hyaline to yellow. Glumes 9-25. 1-1.4 × 0.7-1 $\mathrm{mm}$, deciduous, unicarinate, medially 3 -nervate (including carina), vinaceous to brown at the margins, green to yellowish at the carina, glabrous, aristate; arista $0.5-1.2 \mathrm{~mm}$ long, recurvate $60-90^{\circ}$. Stamina 3; anther 0.15-0.2 $\times 0.1 \mathrm{~mm}$; connective prolongation absent or present at the anther apex, up to $0.1 \mathrm{~mm}$ long, hyaline, reddish to vinaceous, glabrous. Achene $0.5-0.6 \times 0.3 \mathrm{~mm}, 0.3 \mathrm{~mm}$ thick, obovoid, with a mucron $0.1 \mathrm{~mm}$ long.

Material examined: Luís Gomes, Tigre de Cima, nascente do Rio Apodi-Mossoró, 621'26" S, 38²7'42”' W, 30.V.2008, fl. e fr., A.R.O. Ribeiro et al. 199 (EAC, MOSS).

Geographical distribution and phenology: Until now it has been found only in the Inland Forests (Deciduous) in higher altitudes on Serra de Luís Gomes, source of the Apodi-Mossoró river. Flowers and fruits: May.

Comments: As reported by Tucker (1994) and Kukenthal (1936), in C. cuspidatus the number of stamina is variable and the androecium may have 1,2 or 3 stamina. In the Rio Grande do Norte collections, all C. cuspidatus available specimens possessed 3 stamina.

This species may be confused with $C$. squarrosus or $C$. uncinulatus, since it presents recurvate mucron/arista. In C. squarrosus the rachilla is articulate at the base, the spikelet falls as a unity, and the glumes are persistent and medially 7-9-nervate. Its differentiation from C. uncinulatus is more complex, since both have the rachilla is non-articulate, the spikelet is persistent, and the glumes are deciduous and medially 3(5)-nervate. However, in C. cuspidatus plant height reaches $3.5-6.5 \mathrm{~cm}$, the rachilla internode is $0.3-0.5 \mathrm{~mm}$ long, the androecium 3-staminate and the anther 0.15-0.2 mm long, while in C. uncinulatus plant height reaches $6.5-29 \mathrm{~cm}$, the rachilla internode is $0.2-0.3 \mathrm{~mm}$ long, the androecium 1-staminate and the anther $0.4-0.6 \mathrm{~mm}$ long.

7. Cyperus digitatus Roxb., Fl. Ind. 1: 209. 1820.

Fig. 5a-c

Herb cespitose $52-70 \mathrm{~cm}$ tall. Culm 340 $580 \times 5-6 \mathrm{~mm}$, trigonous, transverse septa absent, glabrous, smooth. Leaf blade present, membranaceous, green. Bracts of $1^{\text {st }}$ order 10-14, $45-350 \times 2.3-12 \mathrm{~mm}$. Inflorescence $28 \times 26$ 

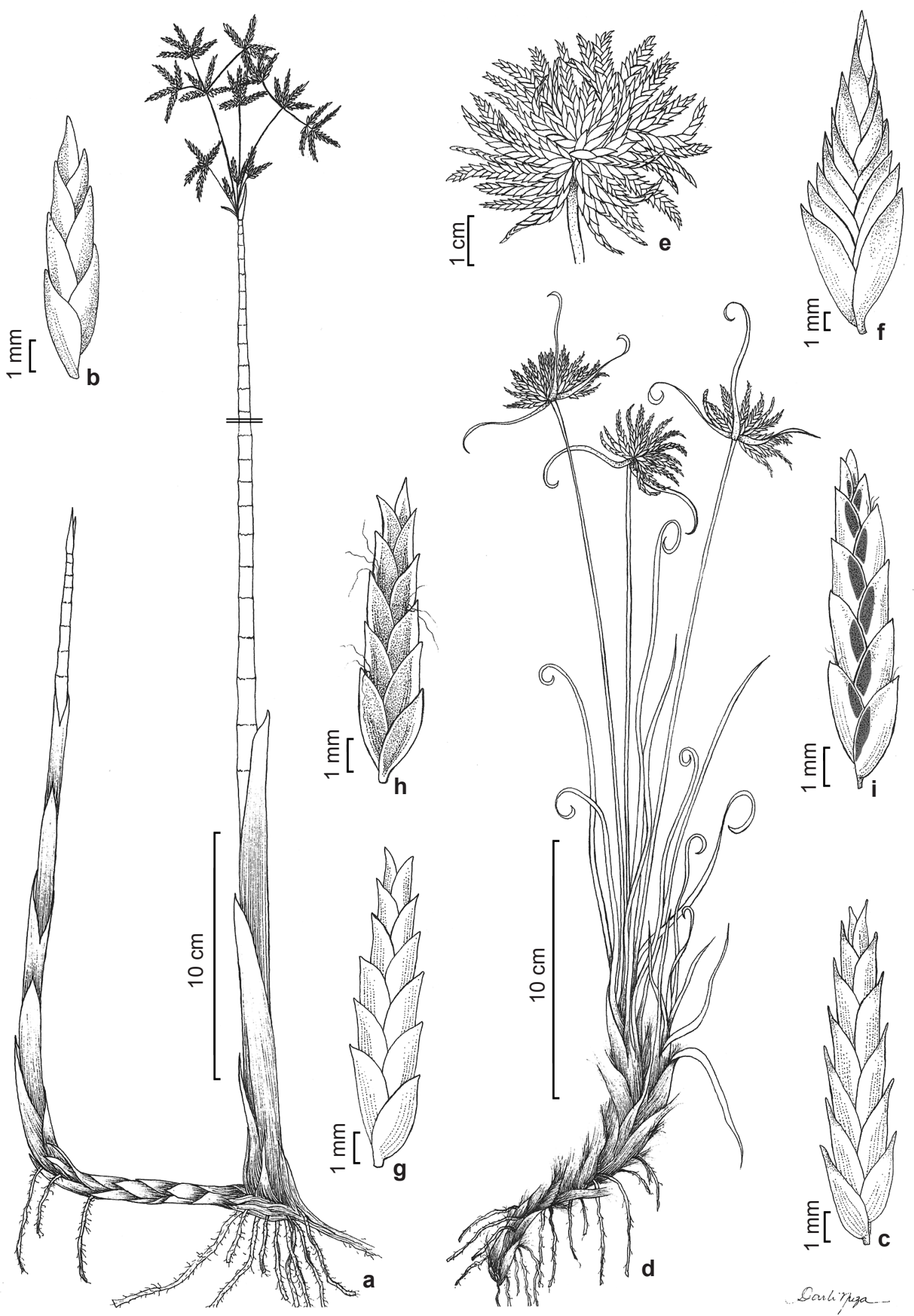

Figure 4 -a-b. Cyperus articulatus - a. habit; b. spikelet. c. C. compressus - spikelet. d-f. C. crassipes - d. habit; e. glomerule; f. spikelet. g. C. esculentus - spikelet. h. C. rotundus - spikelet. i. C. sphacelatus - spikelet (a-b A.R.O. Ribeiro 103; c A.R.O. Ribeiro 129; d-f R.C. Oliveira 2481; g A.R.O. Ribeiro 170; h A.R.O. Ribeiro 161; i A.R.O. Ribeiro et al. 69). 
$\mathrm{cm}$, in 3 orders: antelodium in the $1^{\text {st }}$ and $2^{\text {nd }}$ orders; spike in the ultimate order. Rachis 23-55 $\mathrm{mm}$ long, apparent. Spikelets 10-19 × 1.2-1.5 $\mathrm{mm}, 0.5-0.6 \mathrm{~mm}$ thick. Rachilla non-articulate, spikelet persistent, internodes $0.3-0.6 \mathrm{~mm}$ long, Rachilla wings present, $0.2-0.3 \mathrm{~mm}$ wide, membranaceous, yellow. Glumes 20-43, 1.4-2 $\times 0.6-1 \mathrm{~mm}$, deciduous, unicarinate, medially 7-9-nervate (including carina), yellowish-brown, longitudinally vinaceous-maculate at the margins, yellowish-brown at the carina, glabrous, muticous, rarely mucronate; mucron up to $0.2 \mathrm{~mm}$ long, straight. Stamina 3; anther 0.4-0.6 $\times 0.15-0.2 \mathrm{~mm}$; connective prolongation absent or present at the anther apex, up to $0.1 \mathrm{~mm}$ long, reddish, glabrous. Achene $0.9-1 \times 0.4-0.5 \mathrm{~mm}, 0.3 \mathrm{~mm}$ thick, ovoid or sometimes oblong-ovoid, with a mucron 0.1 $\mathrm{mm}$ long.

Material examined: Jucurutu, RPPN Stoessel de Brito, 25.I.2008, fl. e fr., A.A. Roque 417 (UFRN); Natal, Parque das Dunas, 23.II.1999, fl. e fr., A. Trindade (UFRN 1822, MOSS 11740); 23.XII.2007, fl. e fr., A. Trindade (MOSS 12440); Serra Negra do Norte, Estação Ecológica do Seridó, ao lado do açude, alagados, 6034'68" S, 37015'59' W, 21.V.2005, fl. e fr., R.T. Queiroz 394 (UFRN).

Geographical distribution and phenology: Widely distributed: Atlantic Forest (Evergreen), Inland Forests in higher altitudes (Semideciduous), Caatingas (Hyperxerophilous and Seridó) and Sandbanks. Flowers and fruits: January-February, May, and December.

Comments: can be confused with Cyperus giganteus Vahl, which was not found in Rio Grande do Norte. According to Tucker $(1983 ; 1994), C$. giganteus is $200-350 \mathrm{~cm}$ tall, the leaf is bladeless, the anther $0.7-1 \mathrm{~mm}$ long, and the connective prolongation present at the anther apex and 0.2-0.5 $\mathrm{mm}$ long; in C. digitatus plants are $50-150 \mathrm{~cm}$ tall, the leaf blade present, the anther $0.4-0.5 \mathrm{~mm}$ long, and the connective prolongation absent or present at the anther apex and up to $0.1 \mathrm{~mm}$ long. The occurrence of $C$. giganteus can be eventually confirmed, since its natural habitat also occurs in the state, in addition to the registers of the species in the nearby state of Pernambuco.

\section{Cyperus distans L. f., Suppl. Pl.: 103. 1782.}

Fig. $5 d$

Herb cespitose 52-99 cm tall. Culm 440$860 \times 3.5-5 \mathrm{~mm}$, trigonous, transverse septa absent, glabrous, smooth. Leaf blade present, membranaceous, green. Bracts of $1^{\text {st }}$ order 7-11,
$20-460 \times 1.2-12 \mathrm{~mm}$. Inflorescence $8-36 \times$ $12-26 \mathrm{~cm}$, in $3-4$ orders: antelodium in the $1^{\text {st }}$ and $2^{\text {nd }}$ order; antelodium or spike in the $3^{\text {rd }}$ order; spike in the ultimate order. Rachis $8-36 \mathrm{~mm}$ long, apparent. Spikelets $11-20 \times 1.4-1.6 \mathrm{~mm}$, 0.5-0.6 mm thick. Rachilla non-articulate, spikelet persistent, internodes $0.8-1.1 \mathrm{~mm}$ long. Rachilla wings present, $0.2 \mathrm{~mm}$ wide, membranaceous, hyaline. Glumes 10-21, 1.8-2.2 × 0.9-1.1 mm, deciduous, unicarinate, medially 3-7-nervate (including carina), maroon-vinaceous to brown at the margins, often with a marginal hyaline stripe at the apex, green at the carina, glabrous, muticous, rarely mucronate; mucron up to $0.1 \mathrm{~mm}$ long, straight. Stamina 3, anther $0.3 \times 0.1-0.15 \mathrm{~mm}$; connective prolongation absent or present at the anther apex, up to $0.1 \mathrm{~mm}$ long, reddish, glabrous. Achene 1.4-1.5 × 0.4-0.5 mm, 0.3-0.4 mm thick, lanceoloid to oblanceoloid, with a mucron 0.1 $\mathrm{mm}$ long.

Material examined: Bento Alves, $6^{\circ} 16^{\prime} 40^{\prime \prime} \mathrm{S}$, 38²3'30" W, 17.VI.1980, fl. e fr., O.F. Oliveira et al. 1088 (MOSS); Luís Gomes, estrada para Riacho de Santana, $2 \mathrm{~km}$ após Pitombeiras e 1,6 km antes do Sítio Catingueira, 619'52" S, 38²4'22" W, 31.V.2008, fl. e fr., R.C. Oliveira et al. 2222 (MOSS); Luís Gomes, estrada para Tigre de Cima, margem de afluente do Rio Apodi-Mossoró, próximo a ponte da Baixa do Almeida, $6^{\circ} 23^{\prime} 53^{\prime}$ ' S, 38 $24^{\prime} 36^{\prime}$ W, 30.V.2008, fl. e fr., A.R.O. Ribeiro et al. 177 (MOSS); Martins, Açude Portinho, 605'39" S, 37055'57' W, 25.IV.2006, fl. e fr., M.I.B. Loiola \& R.T. Queiroz 877 (UFRN); Tibau do Sul, Distrito de Pipa, 29.V.2006, fl. e fr., S. Martins \& M. Alves 227 (UFP).

Geographical distribution and phenology: restricted to border of the Atlantic Forest (Evergreen) or Inland Forests in higher altitudes (Semideciduous and Deciduous), and to Sandbank vegetation in the humid eastern coast. Flowers and fruits: April-June.

Comments: recognized by the spikelets arranged in spikes, long rachis $(8-36 \mathrm{~mm})$, rachilla internodes $0.8-1.1 \mathrm{~mm}$ long, and glumes $1.8-2.2$ $\times 0.9-1.1 \mathrm{~mm}$, maroon-vinaceous to brown at the margins, often with a marginal hyaline stripe at the apex, green at the carina, and muticous to rarely mucronate.

9. Cyperus entrerianus Boeckeler, Flora 61: 139. 1878.

Fig. 2 b-d

Herb cespitose $30-79 \mathrm{~cm}$ tall. Culm 70 $670 \times 1.5-3.5 \mathrm{~mm}$, trigonous, transverse septa absent, glabrous, smooth. Leaf blade present, 
membranaceous, green. Bracts of $1^{\text {st }}$ order $6-8$, $19-340 \times 1-5 \mathrm{~mm}$. Inflorescence 3.5-7.5 × 4.6-6.5 $\mathrm{cm}$, in 2-3 orders: antelodium in the $1^{\text {st }}$ order; antelodium, glomerule spherical to hemispherical or spike in the $2^{\text {nd }}$ order; glomerule spherical to hemispherical or spike in the ultimate order. Rachis 1-3 mm long, hidden by spikelets. Spikelets 3-5 $\times 1.6-2 \mathrm{~mm}, 0.3-0.4 \mathrm{~mm}$ thick. Rachilla nonarticulate, spikelet persistent, internodes $0.2-0.3$ $\mathrm{mm}$ long. Rachilla wings absent or present, 0.1 $\mathrm{mm}$ wide, membranaceous, hyaline to vinaceous. Glumes 8-16, 1.2-1.5 × 1-1.2 mm, deciduous, bicarinate, medially $2-3$-nervate (including carinas), green (becoming brown, yellowish-brown or whitish when drying), glabrous, muticous or mucronate; mucron up to $0.1 \mathrm{~mm}$ long, straight. Stamina 1; anther 0.6-0.9 × 0.1-0.15 mm; connective prolongation absent or present at the anther apex, up to $0.1 \mathrm{~mm}$ long, hyaline, glabrous. Achene $0.9-1 \times 0.3-0.4 \mathrm{~mm}, 0.3 \mathrm{~mm}$ thick, lanceoloid to oblanceoloid, with a mucron 0.1 mm long.

Material examined selected: Apodi, 27.IV.1980, fl. e fr., O.F. Oliveira et al. 673 (MOSS); Felipe Guerra, Sítio do Boqueirão, próximo ao Rio Apodi-Mossoró, 5³6'01" S, 37\%41'03" W, 26.IV.2008, fl. e fr., A.R.O. Ribeiro et al. 151 (MOSS); Governador Dix-Sept Rosado, Serrote do Boi, próximo ao Rio Apodi-Mossoró, 5²2'37' S, 37²9'30" W, 26.IV.2008, fl. e fr., A.R.O. Ribeiro et al. 150 (MOSS); Luís Gomes, estrada para Tigre de Cima, margem de afluente do Rio Apodi-Mossoró, próximo a ponte da Baixa do Almeida, 6²3'53" S, 38 24'36" W, 30.V.2008, fl. e fr., A.R.O. Ribeiro et al. 178 (MOSS); Luís Gomes, Tigre de Cima, nascente do Rio ApodiMossoró., 6²0'42" S, 38²7'27' W, 5.X.2007, fl. e fr., A.R.O. Ribeiro et al. 10 (MOSS); Mossoró, 4.XII.1996, fl. e fr., M.E.G. de Lima \& M.Z. Alves 7 (MOSS); Passa e Fica, $3 \mathrm{~km}$ do portal de entrada da cidade, 6 ${ }^{\circ} 24^{\prime} 20^{\prime \prime}$ S, 35³9'28" W, 14.V.2009, fl. e fr., R. C. Oliveira et al. 2392 (MOSS); São Paulo do Potengi, 4 km após o trevo Riachuelo-São Paulo do Potengi, 5'52'42" S, 35'45'77" W, 14.V.2009, fl. e fr., R.C. Oliveira et al. 2372 (MOSS); São Vicente, Serra de Santana, 6¹1'33" S, 36²' $05^{\circ}$ "W, 16.VIII.2009, fl. e fr., J.L.Costa-Lima et al. 258 (UFRN); Serra Negra do Norte, 10.VI.1980, fl. e fr., O.F. Oliveira et al. 1005 (MOSS).

Geographical distribution and phenology: Widely distributed: Inland Forests (Semideciduous and Deciduous), Riparian Forest with Carnauba, and Caatingas (Hypoxerophilous, Hyperxerophilous, and Seridó) to Saline Desert. Flowers and fruits: April-June, August, October, and December.

Comments: There is divergence with regard to the classification of this species. Denton (1978) and Araújo \& Longhi-Wagner (1996) treated it as a variety of $C$. luzulae. The present work follows Kükenthal (1936), Tucker (1994), Luceño et al. (1997) and Guarise \& Vegetti (2007), in which it was raised to the species level. Similarly, as reported by Tucker (1994), it was found allopatric distribution between C. entrerianus and C. luzulae, besides significant morphological differences between them. In Rio Grande do Norte, $C$. entrerianus is distributed from less humid to dry areas, both in the Caatinga and in relicts of forest formations present at higher altitudes. The occurrence of $C$. luzulae was registered only at the humid eastern coast, in an area of Cerrado, in the municipality of Canguaretama.

In $C$. entrerianus the spikelets are disposed in spherical to hemispherical glomerules or globose spikes with short rachis (1-3 mm long); the glumes are greenish, becoming brown when dehydrating; the anthers are 0.6-0.9 mm long. In C. luzulae the spikelets, which have long rachises (3.5-12 $\mathrm{mm}$ long), are arranged in spikes; the glumes are white, becoming brown during the process of preparing herbarium specimens; the anthers are $0.4-0.5 \mathrm{~mm}$ long.

It is possible that $C$. entrerianus be confused also with $C$. surinamensis. In $C$. entrerianus the culms are glabrous (vs. retrorsely scabrous to rarely glabrous in C. surinamenis) and the achene is 0.9-1 $\mathrm{mm}$ long (vs. 0.6-0.8 mm long in C. surinamenis). Additionally, C. surinamenis has spikelets arranged in serial fascicles (not in glomerules or globose spikes as in C. entrerianus) and rachis $0.3-0.5 \mathrm{~mm}$ long (shorter than in C. entrerianus).

10. Cyperus esculentus L., Sp. Pl.: 45 (1753).

Fig. $4 \mathrm{~g}$

Herb cespitose 37-60 cm tall. Culm 320$540 \times 1-1.9 \mathrm{~mm}$, trigonous, transverse septa absent, glabrous, smooth. Leaf blade present, membranaceous, green. Bracts of $1^{\text {st }}$ order 5 , $10-140 \times 1.6-3.6 \mathrm{~mm}$. Inflorescence 5-8 × 3-4 $\mathrm{cm}$, in 2 orders: antelodium in the $1^{\text {st }}$ order; spike subdigitate, rarely digitate group in the ultimate order. Rachis 0.5-10 mm long, apparent. Spikelets $6.3-22 \times 1.8-2.8 \mathrm{~mm}, 0.4-0.5 \mathrm{~mm}$ thick. Rachilla non-articulate, spikelet persistent, internodes 0.6-0.8 mm long. Rachilla wings present, $0.2 \mathrm{~mm}$ wide, membranaceous, ferruginous. Glumes 7-30, 2.8-3.4 × 1.4-1.6 mm, persistent, unicarinate, medially 7-11-nervate (including carina), brown to ochraceous at the margins, green (sometimes 
brown) at the carina, glabrous, muticous or mucronate; mucron up to $0.3 \mathrm{~mm}$ long, straight. Stamina 3, anther 1.1-1.8 × 0.15-0.2 mm; connective prolongation absent or present at the anther apex, up to $0.1 \mathrm{~mm}$ long, reddish, glabrous. Achene (1.1)1.3-1.5(1.6) × 0.3-0.6(0.8) mm, 0.3$0.6(0.8) \mathrm{mm}$ thick, obovoid, sometimes ellipsoidal or ovoid, with a mucron $0.1 \mathrm{~mm}$ long.

Material examined: Governador Dix-Sept Rosado, Serrote do Boi, próximo ao Rio Apodi-Mossoró,

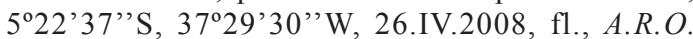
Ribeiro et al. 213 (MOSS), Mossoró, margem do Rio Apodi-Mossoró, próximo ao Cartódromo, $5^{\circ} 11^{\prime} 56^{\prime}$ " S, 37 $7^{\circ} 19^{\prime} 42$ " W, 21.V.2008, fl., A.R.O. Ribeiro 170 (MOSS, UB).

Geographical distribution and phenology: Always associated with the impact of human activities in areas of Riparian Forest with Carnauba and Caatinga Hyperxerophilous. Flowers and fruits: May.

Comments: Since no achenes were available in the analyzed material, the description of this character was based on Tucker (1994).

Can be mistaken for $C$. rotundus because of its persistent glumes and spikelets. Nevertheless, in C. esculentus the glumes are brown to ochraceous at the margins and rachilla internodes 0.6-0.8 $\mathrm{mm}$ long, whereas in C. rotundus the glumes are vinaceous to rarely brown-vinaceous at the margins and rachilla internodes 0.9-1.4 mm long.

According to Hefler \& Longhi-Wagner (2012), C. esculentus and C. rotundus can also be distinguished by leaves and arrangement of tubers. In C. esculentus the stolon-like rhizomes have distal tubers and the adaxial ligule is absent on the leaves. Already in Crotundus the stolon-like rhizomes have intercalary tubers and the adaxial ligule formed by a reduced membrane is present on the leaves.

Cyperus esculentus is commonly known as yellow nutsedge (tiririca-amarela or junça in Brazil) and referred as a weed of relevant agricultural importance, but less aggressive than $C$. rotundus. The impact of C. esculentus as a weed has been reported in connection with 21 crop species in about 40 countries (Bendixen \& Nandihalli 1987). However, in spite of its undesirable effects as a crop invader, its tubers, which are edible and resemble nuts, are marketed under the name of chufa.

11. Cyperus haspan L., Sp. Pl.: 45. 1753. Fig. 3c Herb cespitose 19-60 cm tall. Culm 100-520 $\times 1.2-6 \mathrm{~mm}$, trigonous, transverse septa absent, glabrous, smooth. Leaf blade absent or present, membranaceous, green. Bracts of $1^{\text {st }}$ order $2-3$,
$14-92 \times 1.8-6 \mathrm{~mm}$. Inflorescence 3-7.5 × 3.5-11.5 $\mathrm{cm}$, in $2-4$ orders: antelodium in the $1^{\text {st }}$ order; antelodium, digitate group or subdigitate spike in the $2^{\text {nd }}$ and $3^{\text {rd }}$ orders; subdigitate spike or digitate group in the ultimate order. Rachis $0.5-1 \mathrm{~mm}$ long, apparent. Spikelets 5-12 × 1-1.5 mm, 0.4-0.6 mm thick. Rachilla non-articulate, spikelet persistent, internodes $0.4-0.6 \mathrm{~mm}$ long. Rachilla wings absent or present, $0.1-0.2 \mathrm{~mm}$ wide, membranaceous, hyaline to vinaceous. Glumes $12-23,1.2-1.4$ $\times 0.7-1 \mathrm{~mm}$, deciduous, unicarinate, medially 1-3-nervate (including carina), yellowish to vinaceous at the margins, brown to yellowish at the carina, glabrous, mucronate, rarely muticous; mucron up to $0.2 \mathrm{~mm}$ long, straight. Stamina 3 ; anther $0.4-0.6 \times 0.1-0.15 \mathrm{~mm}$; connective prolongation absent or present at the anther apex, up to $0.1 \mathrm{~mm}$ long, white to ferruginous, glabrous to antrorsely scabrous. Achene $0.4-0.6 \times 0.3-0.4 \mathrm{~mm}$, $0.3-0.4 \mathrm{~mm}$ thick, spheroidal, ovoid to very largely ovoid or obovoid, with a mucron $0.1 \mathrm{~mm}$ long. Material examined: Baía Formosa, margem de riacho na entrada da vila da praia do Sagi, 6 $67^{\prime} 54^{\prime \prime}$ S, 34 $58^{\circ} 47^{\prime \prime}$ W, 2.XI.2007, fl. e fr., A.R.O. Ribeiro et al. 30 (EAC, MOSS); Canguaretama, Barra do Cunhaú, cerca de $3 \mathrm{~km}, 6^{\circ} 19^{\prime} 43^{\prime \prime} \mathrm{S}, 35^{\circ} 03^{\prime} 44^{\prime \prime} \mathrm{W}, 3 . X \mathrm{XI} .2007$, fl. e fr., A.R.O. Ribeiro et al. 55 (MOSS); Coronel João Pessoa, 25.V.1981, fl. e fr., O.F. Oliveira et al. 1852 (MOSS); Natal, Projeto Rio Jaguaribe, 24.IV.2006, fl. e fr., R.M. Soares et al. 67 (MOSS, UFRN); Natal, Genipabu, 3.VIII.1994, fl. e fr., M. Luceño 233 (UFP).

Geographical distribution and phenology: registered in the humid eastern coast (Atlantic Forest Evergreen, Cerrado, and Sandbanks) and Inland Forests in higher altitudes (Semideciduous and Deciduous). Flowers and fruits: April-May, August, and November.

Comments: can be confused with $C$. amabilis (v. comments under this species). It was observed large variation in character states of leaves, inflorescences, and achenes in the collections of C. haspan from Rio Grande do Norte: leaf blades may be absent or present; inflorescences vary from lax and branched to contracted and few-branched; achene shape varies from spheroidal or obovoid to ovoid. Tucker (1994) and Luceño et al. (1997) also found large variation in such characters in this species. On the other hand, Araújo \& LonghiWagner (1996) reported uniformity in this species with regard to the vegetative part, but found that its inflorescence varies largely in the plants from Rio Grande do Sul, which led these authors to accept two varieties in their taxonomic treatment. 
12. Cyperus hermaphroditus (Jacq.) Standl., Contr. U. S. Natl. Herb. 18: 88. $1916 . \quad$ Fig. 2e-g Herb cespitose $23-67 \mathrm{~cm}$ tall. Culm 200$605 \times 1-4 \mathrm{~mm}$, trigonous, transverse septa absent, glabrous, smooth. Leaf blade present, membranaceous, green. Bracts of $1^{\text {st }}$ order 3-6, $10-170 \times 0.9-4.5 \mathrm{~mm}$. Inflorescence 0.9-12.5 $\times$ $1.1-12.5 \mathrm{~cm}$, in 1-2 orders: antelodium or spike in the $1^{\text {st }}$ order; spike in the ultimate order. Rachis 6-15 mm long, apparent. Spikelet 3.3-13 $\times 0.8-2.1$ $\mathrm{mm}, 0.8-1.1 \mathrm{~mm}$ thick. Rachilla articulate at the base, spikelet falling as a unity, internodes 1.5-2.3 $\mathrm{mm}$ long. Rachilla wings present, $0.5-0.8 \mathrm{~mm}$ wide, membranaceous, brown to hyaline, with ferruginous, vinaceous or maroon areas. Glumes 3-6, 3.9-4.9 × 1.5-1.8 mm, persistent, unicarinate, medially 11-15-nervate (including carina), brown to yellowish, with ferruginous, vinaceous or maroon areas at the margins, green at the carina, glabrous, muticous or mucronate; mucron up to $0.2 \mathrm{~mm}$ long, straight. Stamina 3; anther 0.7-1.3 $\times 0.1-0.2 \mathrm{~mm}$, connective prolongation absent or present at the anther apex, up to $0.1 \mathrm{~mm}$ long, reddish to vinaceous, glabrous. Achene 2.3-3 $\times 0.6-0.8 \mathrm{~mm}, 0.6-0.7 \mathrm{~mm}$ thick, lanceoloid to oblanceoloid or narrowly oblong, with a mucron $0.1 \mathrm{~mm}$ long.

Material examined: Natal, Genipabu, 3.VIII.1994, fl. e fr., M. Luceño 224 (UFP); Natal, IBAMA, Parque das Dunas, 6.XI.1996, fl. e fr., A.P. Mendes \& A.C. Settini 400 (UFP); Natal, Parque das Cidades, San Vale, dunas atrás do SEST/SENAT, 5051'19"'S, 3514'15"'W, 28.V.2007, fl. e fr., V.R.R. Sena et al. 103 (UFRN); Natal, Parque das Dunas, 5049'30" S, 35¹1' W, 9.VI.1997, fl. e fr., L.A. Cestaro 97-0021 (UFRN); Natal, Parque das Dunas, Trilha da peroba, 21.VII.2005, fl. e fr., I. Loiola et al. (MOSS 11741); 16.VII.1994, fl. e fr., J.A. Fontenele

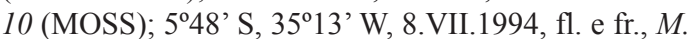
Araújo Junior (MOSS 5569); Tibau do Sul, Praia de Pipa, 4.VIII.1995, fl. e fr., M. Luceño 355 (UFP).

Geographical distribution and phenology: restricted to the Sandbanks at the humid eastern coast. Flowers and fruits: May-August, November.

Comments: recognized by the spikelets lanceoloid to subulate, maroon to ferruginous, disposed in spikes with long rachis $(6-15 \mathrm{~mm}$ long). The achenes (2.3-3 mm long) were longer than reported by Tucker (1994), Adams (1994) and Hefler \& Longhi-Wagner (2012).

Large variations in the dimensions of some characters were found in the specimen M. Luceño 224: in the same plant, it was found spikelets 7-13 $\mathrm{mm}$ long and achenes $2.3-2.8 \mathrm{~mm}$ long.
13. Cyperus iria L., Sp. Pl.: 45. $1753 . \quad$ Fig. 5e Herb cespitose $36.5-82 \mathrm{~cm}$ tall. Culm $300-680 \times 1.9-3.6 \mathrm{~mm}$, trigonous, transverse septa absent, glabrous, smooth. Leaf blade present, membranaceous, green. Bracts of $1^{\text {st }}$ order 4-7, 9-130 × 0.4-5.5 mm. Inflorescence $6.5-13 \times 6-15 \mathrm{~cm}$; in 3-4 orders: antelodium in the $1^{\text {st }}$ order; antelodium or spike in the $2^{\text {nd }}$ and $3^{\text {rd }}$ orders; spike in the ultimate order. Rachis 1.2-33 $\mathrm{mm}$ long, apparent. Spikelets 4.5-9.5 × 1.5-2 $\mathrm{mm}, 0.5-0.7 \mathrm{~mm}$ thick. Rachilla non-articulate, spikelet persistent, internodes $0.5-0.7 \mathrm{~mm}$ long. Rachilla wings absent or present, $0.1 \mathrm{~mm}$ wide, membranaceous, hyaline to a vinaceous. Glumes 6-17, 1.2-1.6 × 1.4-1.8 mm, deciduous, unicarinate, medially 3-5-nervate (including carina), yellow to yellowish-brown at the margins, with a marginal hyaline stripe at the apex, green at the carina, glabrous, mucronate, rarely muticous; mucron up to $0.2 \mathrm{~mm}$ long, straight. Stamina 2; anther $0.3-0.4(0.7) \times 0.1-0.15 \mathrm{~mm}$; connective prolongation absent or present at the anther apex, up to $0.1 \mathrm{~mm}$ long, hyaline, ferruginous, reddish to vinaceous, glabrous. Achene 1.1-1.2 $\times 0.4-0.6$ $\mathrm{mm}, 0.4-0.5 \mathrm{~mm}$ thick, obovoid to oblanceoloid, sometimes ellipsoidal or ovoid, with a mucron $0.1 \mathrm{~mm}$ long.

Material examined: Luís Gomes, estrada para Cachoeira do Rela, margem de afluente do Rio ApodiMossoró, 623'51" S, 38²2'52" W, 31.V.2008, fl. e fr., A.R.O. Ribeiro et al. 208 (MOSS); Luís Gomes, estrada para Tigre de Cima, margem de afluente do Rio Apodi-Mossoró, próximo a ponte da Baixa do Almeida, $6^{\circ} 23^{\prime} 53^{\prime \prime}$ S, 38 $24^{\prime} 36^{\prime \prime}$ W, 30.V.2008, fl. e fr., A.R.O. Ribeiro et al. 172 (MOSS); Mossoró, margem de lago próximo à Feira do Bode, próximo ao Rio Apodi-

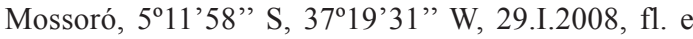
fr., A.R.O. Ribeiro 101 (EAC, MOSS); 28.II.2008, fl. e fr., A.R.O. Ribeiro 119 (MOSS); 28.III.2008, fl. e fr., A.R.O. Ribeiro 128 (MOSS); 24.IV.2008, fl. e fr., A.R.O. Ribeiro \& A.M.S. Araújo 139 (MOSS); 21.V.2008, fl. e fr., A.R.O. Ribeiro 160 (MOSS); Mossoró, margem do Rio Apodi-Mossoró, próximo ao Cartódromo, $5^{\circ} 11^{\prime} 56^{\prime}$ ' S, 37019'42" W, 24.IV.2008, fl. e fr., A.R.O. Ribeiro \& A.M.S. Araújo 149 (MOSS); Tibau do Sul, Distrito de Pipa, 29.V.2006, fl. e fr., S. Martins \& M. Alves 228 (UFP).

Geographical distribution and phenology: registered in the Atlantic Forest (Evergreen), Inland Forests in higher altitudes (Semideciduous and Deciduous), Riparian Forest with Carnauba, Caatinga Hyperxerophilous, and Sandbanks (only at the humid eastern coast). Flowers and fruits: January-May. 
Comments: recognized by the spikelets (4.5$9.5 \times 1.5-2 \mathrm{~mm})$ arranged in spikes and the glumes $(1.2-1.6 \times 1.4-1.8 \mathrm{~mm})$ largely obovate, yellow to yellowish-brown at margins, with a marginal hyaline stripe at the apex, green at the carina.

14. Cyperus laxus Lam., Tabl. Encycl. 1: 146. 1791.

Fig. 3d

Herb cespitose $22-76 \mathrm{~cm}$ tall. Culm 170-630 $\times 0.9-2.5 \mathrm{~mm}$, trigonous, transverse septa absent, glabrous, smooth, rarely antrorsely scabrous at the apex. Leaf blade present, membranaceous, green. Bracts of $1^{\text {st }}$ order $6-9,16-210 \times 0.8-6$ $\mathrm{mm}$. Inflorescence $4-15 \times 6-24 \mathrm{~cm}$, in 2-3 orders: antelodium in the $1^{\text {st }}$ order; antelodium, digitate group or subdigitate spike in the $2^{\text {nd }}$ order; digitate group or subdigitate spike in the ultimate order. Rachis $0.4-1.5 \mathrm{~mm}$ long, apparent. Spikelets 5-11 $\times 1.8-2.3 \mathrm{~mm}, 0.9-1.1 \mathrm{~mm}$ thick. Rachilla nonarticulate, spikelet persistent, internodes $0.6-0.8$ $\mathrm{mm}$ long. Rachilla wings absent or present, $0.1-0.2$ $\mathrm{mm}$ wide, membranaceous, hyaline to vinaceous. Glumes 6-16, 1.2-1.5 × 1.6-2.2 mm, deciduous, unicarinate, medially 9-15-nervate (including carina), brown to yellowish-brown, sometimes with the margins ferruginous-maculate, green to brown at the carina, glabrous to antrorsely scabrous at the carina apex, aristate to mucronate; mucron $0.3-0.7 \mathrm{~mm}$ long, straight or recurvate at an angle up to $45^{\circ}$. Stamina 3 ; anther $0.5-0.7 \times 0.1-0.15$ $\mathrm{mm}$; connective prolongation present at the anther apex, $0.1-0.2 \mathrm{~mm}$ long, vinaceous, with antrorse bristles. Achene 1.3-1.6 × 0.8-1 mm, 0.6-0.9 mm thick, obovoid, sometimes ellipsoidal or ovoid, mucron $0.1 \mathrm{~mm}$ long.

Material examined: Canguaretama, Barra do Cunhaú, ca. $3 \mathrm{~km}, 6^{\circ} 19^{\prime} 43^{\prime}$ ' S, $35^{\circ} 03^{\prime} 44^{\prime}$ " W, 3.XI.2007, fl. e fr., A.R.O. Ribeiro et al. 44 (EAC, MOSS); Coronel João Pessoa, 18.VI.1980, fl. e fr., O.F. Oliveira et al. 1157 (MOSS); O.F. Oliveira et al. 1158 (MOSS); Luís Gomes, estrada para Cachoeira do Rela, próximo às palmeiras com orquídeas, margem de afluente do Rio ApodiMossoró, 6023'50" S, 38²2'51" W, 31.V.2008, fl. e fr., A.R.O. Ribeiro et al. 206 (MOSS); Luís Gomes, Tigre de Cima, nascente do Rio Apodi-Mossoró, 6²1'42" S, $38^{\circ} 27^{\prime} 49^{\prime \prime}$ W, 30.V.2008, fl. e fr., A.R.O. Ribeiro et al. 195 (MOSS); 6022'88” S, 38²8'54” W, 24.VIII.2007, fl. e fr., A.R.O. Ribeiro et al. 4 (MOSS); Martins, Sítio Gruta, $6^{\circ} 05^{\prime} 45^{\prime}$ 'S, $37^{\circ} 55^{\prime} 46^{\prime}$ 'W, 25.IV.2006, fl. e fr., R.T. Queiroz 786 (UFRN); Natal, Sítio Gruta, 25.IV.2006, fl. e fr., R.T. Queiroz 786 (MOSS); Parnamirim, EMPARN, 17.II.2006, fl. e fr., R.T. Queiroz \& M.Z. Cardoso 596 (UFRN, MOSS); Serrinha dos Pintos, Sítio Serrinha do Canto, 27.III.2005, fl. e fr., R.T. Queiroz 135 (UFRN).
Geographical distribution and phenology: restricted to the Cerrado, Atlantic Forest (Evergreen), and Inland Forests in higher altitudes (Semideciduous and Deciduous). Flowers and fruits: February-June, August, and November.

Comments: recognized by: spikelets (5-11 $\times 1.8-2.3 \mathrm{~mm}$ ) arranged in a digitate group or subdigitate spike, rachis $0.4-1.5 \mathrm{~mm}$ long; glumes $(1.2-1.5 \times 1.6-2.2 \mathrm{~mm})$ aristate to mucronate, brown to yellowish-brown (sometimes with ferruginous areas at the margins), green to brown at the carina, with a mucron $0.3-0.7 \mathrm{~mm}$ long, straight or recurvate up to a $45^{\circ}$ angle; connective prolongation with antrorse bristles; achene 1.3-1.6 mm long.

In O.F. Oliveira et al. 1157, A.R.O. Ribeiro et al. 4 and R.T. Queiroz 786, it was observed culms antrorsely scabrous at the edges of the apical portion. According to Tucker (1994), culms sparsely scabrous at the apex are uncommon in C. laxus.

15. Cyperus ligularis L., Amoen. Acad. 5: 31. 1760.

Fig. $5 \mathrm{f}-\mathrm{g}$

Herb cespitose $43-140 \mathrm{~cm}$ tall. Culm 370 $1220 \times 3-7 \mathrm{~mm}$, trigonous, transverse septa absent, glabrous, papillose. Leaf blade present, chartaceous, glaucous. Bracts of $1^{\text {st }}$ order 6-10, 19-340 $\times 0.8-10$ $\mathrm{mm}$. Inflorescence $4-15.5 \times 5.5-18 \mathrm{~cm}$, in 3 orders: antelodium in the $1^{\text {st }}$ order; antelodium or spike in the $2^{\text {nd }}$ order; spike in the ultimate order. Rachis $3.5-15 \mathrm{~mm}$ long, hidden by spikelets. Spikelets $3.5-8 \times 1.4-1.8 \mathrm{~mm}, 0.7-0.8 \mathrm{~mm}$ thick. Rachilla articulate at the base, spikelet falling as a unity, internodes $0.4-0.8 \mathrm{~mm}$ long. Rachilla wings present, $0.4-0.8 \mathrm{~mm}$ wide, membranaceous, brown, greenish-brown or hyaline, sometimes vinaceousmaculate. Glumes 5-8, 2.2-2.6 × 1.2-1.8 mm, persistent, unicarinate, medially $9-15$-nervate (including carina), brown-vinaceous, sometimes brown at the margins, green at the carina, glabrous, muticous, rarely mucronate; mucron up to $0.1 \mathrm{~mm}$ long, straight. Stamina 3; anther 0.4-0.6 $\times 0.15-0.2$ $\mathrm{mm}$; connective prolongation absent or present at the anther apex, $0.1 \mathrm{~mm}$ long, vinaceous, glabrous. Achene $1.2-1.6 \times 0.5-0.7 \mathrm{~mm}, 0.5-0.7 \mathrm{~mm}$ thick, ovoid to lanceoloid, ellipsoidal or obovoid, mucron $0.1 \mathrm{~mm}$ long.

Material examined selected: Areia Branca, Salina Augusto Severo, 11.V.2007, fl. e fr., A.A. Roque \&. A.C.P. Oliveira 55 (UFP, UFRN); Baía Formosa, entrada para Vila do Sagi, 6027'51”'S, 3458'40”'W, 1.XI.2007, 
fl. e fr., A.R.O. Ribeiro et al. 23 (EAC, MOSS); Caicó, RN 288 sentido Currais Novos, entra da cerca de $1 \mathrm{~km}$ da cidade, vicinal para a Serra da Formiga, $13 \mathrm{~km}$ da estrada, próximo a um córrego, 6²2'59' S, 36 59 '12" W, 15.VIII.2009, fl. e fr., J.G. Jardim et al. 5537 (UFRN); Governador Dix-Sept Rosado, Sítio Pedrinha, margem do Rio Apodi-Mossoró, 5¹9'47' S, 37²7'42"'W, 22.II.2008, fl. e fr., A.R.O. Ribeiro et al. 111 (MOSS); Jardim do Seridó, Sítio Catururé, margens do Rio Seridó, debaixo da ponte de Zé de Bastos, 15.III.2009, fl. e fr., A.A. Roque 716 (UFRN); Jucurutu, RPPN Stoessel de Britto, 29.XII.2008, fl. e fr., A.A. Roque 370 (UFRN); Martins, Açude Portinho, 605'39' S, 37 55 '57' W, 25.IV.2006, fl. e fr., M.I.B. Loiola 878 (MOSS, UFRN); Mossoró, margem de lago próximo à Feira do Bode, próximo ao Rio Apodi-Mossoró, 5¹1'58' S, 37¹9'31', W, 19.X.2007, fl. e fr., A.R.O. Ribeiro 19 (MOSS); Natal, Genipabu, aos Arredores do Alagado próx. ao Acesso da Praia, 8.XI.1996, fl. e fr., A.P. Mendes \& A.C. Settini 415 (UFP); São Paulo do Potengi, logo após o trevo São Paulo do Potengi-Senador Elói de Souza, 14.V.2009, fl. e fr., R.C. Oliveira et al. 2380 (MOSS).

Geographical distribution and phenology: Widely distributed: border of the Atlantic Forest (Evergreen), Riparian Forest with Carnauba, Caatingas (Hypoxerophilous, Hyperxerophilous, and Seridó), Sandbanks, and Saline Desert. Flowers and fruits: January-June, August-December.

Comments: recognized by culms papillose, leaf blades chartaceous, glaucous, and spikelets vinaceous to brown-vinaceous, arranged in dense spikes hidden by the spikelets. It is morphologically close to species Cyperus sp. 1, which presents similar culms and leaf blades, but can be distinguished by the inflorescence.

In C. ligularis the spikelet is 3.5-8 mm long, the rachilla internode $0.4-0.8 \mathrm{~mm}$ long, the glumes 5-8 per spikelet and 2.2-2.6 mm long. In Cyperus sp. 1 the spikelet is $6-14 \mathrm{~mm}$ long, the rachilla internode $0.9-1.2 \mathrm{~mm}$ long, the glumes (5)7-11 per spikelet and $2.7-3 \mathrm{~mm}$ long.

In A.R.O. Ribeiro et al. 23 (EAC, MOSS), the $1^{\text {st }}$ order rays are very short and the inflorescence is glomerule-like and compact, giving the impression of having a single order.

16. Cyperus luzulae (L.) Rottb. ex Retz., Observ. Bot. 4: 11. 1786.

Fig. $2 \mathrm{~h}$

Herb cespitose $32-51.5 \mathrm{~cm}$ tall. Culm $195-460 \times 1.6 \mathrm{~mm}$, trigonous, transverse septa absent, glabrous, smooth. Leaf blade present, membranaceous, green. Bracts of $1^{\text {st }}$ order 7 , 13-185 × 0.5-3.4 mm. Inflorescence 1.8-5.5 $\times$ $2.8-3.4 \mathrm{~cm}$, in 3 orders: glomerule hemispherical or antelodium in the $1^{\text {st }}$ order; spike in the $2^{\text {nd }}$ and ultimate orders. Rachis $3.5-12 \mathrm{~mm}$ long, hidden by spikelets. Spikelets $8-4.8 \times 1.9-2.8 \mathrm{~mm}, 0.3 \mathrm{~mm}$ thick. Rachilla non-articulate, spikelet persistent, internodes $0.2-0.3 \mathrm{~mm}$ long. Rachilla wings absent or present, $0.1 \mathrm{~mm}$ wide, membranaceous, hyaline. Glumes $8-14,1.3-1.7 \times 0.7-0.9 \mathrm{~mm}$, deciduous, bicarinate, medially 2-nervate (including carinas), white, becoming brown when dehydrating, glabrous, muticous, sometimes mucronate; mucron up to $0.1 \mathrm{~mm}$ long, straight. Stamen 1; anther 0.4$0.5 \times 0.15-0.2 \mathrm{~mm}$; connective prolongation absent or present at the anther apex, up to $0.1 \mathrm{~mm}$ long, vinaceous, glabrous. Achene $0.8-0.9 \times 0.3-0.4 \mathrm{~mm}$, $0.2-0.3 \mathrm{~mm}$ thick, ovoid to lanceoloid, ellipsoidal or obovoid, mucron $0.1 \mathrm{~mm}$ long.

Material examined: Canguaretama, Barra do Cunhaú, ca. $3 \mathrm{~km}, 6^{\circ} 19^{\prime} 43^{\prime}$ ' S, $35^{\circ} 03^{\prime} 44^{\prime \prime}$ 'W, 3.XI.2007, fl. e fr., A.R.O. Ribeiro et al. 49 (EAC, MOSS).

Geographical distribution and phenology: registered until this moment only in Cerrado, municipality of Canguaretama. Flowers and fruits: November.

Comments: recognized by the antelodia of white spikes and glumes bicarinate. It may be confused with $C$. entrerianus (v. comments under this species).

17. Cyperus odoratus L., Sp. Pl.: 46. 1753.

Fig. $2 i-j$

Herb cespitose $27-121 \mathrm{~cm}$ tall. Culm $200-1030 \times 1.2-5.5 \mathrm{~mm}$, trigonous, transverse septa absent, glabrous, smooth. Leaf blade present, membranaceous, green. Bracts of $1^{\text {st }}$ order 6-14, 17-570 × 1.5-11 mm. Inflorescence $5.5-20 \times 5-19 \mathrm{~cm}$, in 2-4 orders: antelodium in the $1^{\text {st }}$ order; antelodium or spike in the $2^{\text {nd }}$ order; spike in the $3^{\text {rd }}$ and ultimate orders. Rachis $3-12$ mm long, apparent. Spikelets $12-34 \times 0.9-1.5$ $\mathrm{mm}, 0.6-1.1 \mathrm{~mm}$ thick. Rachilla articulate at the base and all nodes, spikelet splitting into unities composed of rachilla 1 internode +1 glume +1 achene, internodes $1.3-2 \mathrm{~mm}$ long. Rachilla wings present, $0.6-1.3 \mathrm{~mm}$ wide, spongy, becoming membranaceous at the margins, yellowish-brown to ochraceous. Glumes $5-16,2.2-3.4 \times 1.2-2.8$ $\mathrm{mm}$, persistent, unicarinate, medially 5-9-nervate (including carina), brown, ferruginous or vinaceous at the margins, green at the carina, glabrous, muticous or mucronate; mucron up to $0.1 \mathrm{~mm}$ long, straight. Stamina 3; anther 0.4-0.7 $\times 0.1-0.2$ $\mathrm{mm}$; connective prolongation absent or present 
at the anther apex, up to $0.1 \mathrm{~mm}$ long, vinaceous to reddish, glabrous. Achene 1.5-1.8 × 0.5-0.6 $\mathrm{mm}, 0.4-0.6 \mathrm{~mm}$ thick, oblanceoloid to oblongoblanceoloid, with a mucron $0.1 \mathrm{~mm}$ long.

Material examined selected: Alexandria, 3.X.1994, fl. e fr., J.M. Silva da 2 (MOSS); Apodi, Lajedo de Soledade, 5³5'37' S, 3749'37' W, 2.VII.2006, fl. e fr., R.T. Queiroz 1063 (MOSS, UFRN); Campo Redondo, Fazenda Giromão, 5.VIII.2009, fl. e fr., A.A. Roque 1053 (UFRN); Grossos, Salina Salmar, 29.VI.2007, fl. e fr., A.A. Roque 267 (UFP, UFRN); Itaú, 6¹6'86" S, 38 $15^{\prime} 71^{\prime \prime}$ W, 20.VIII.2007, fl. e fr., G.H.G. Silva et al. 23 (MOSS); Mossoró, próximo à Ponte de Ferro, Rio Mossoró, 511'15" S, 37²0'39”' W, 11.I.2008, fl. e fr., A.R.O. Ribeiro \& A.S. Silva 96 (MOSS); Natal, 10.III.1993, fl. e fr., L. Leal (MOSS); Passa e Fica, na saída para Nova Cruz, 6²6'32' S, 35³7'70" W, 14.V.2009, fl. e fr., R.C. Oliveira et al. 2396 (MOSS); São Paulo do Potengi, 4 km após o trevo Riachuelo-São Paulo do Potengi, 5'52'42" S, 3545'77' W, 14.V.2009, fl. e fr., R.C. Oliveira et al. 2371 (MOSS); Serra Negra do Norte, Estação Ecológica do Seridó, próximo ao açude, 1.V.2005, fl. e fr., R.T. Queiroz 302 (HUEFS).

Geographical distribution and phenology: Widely distributed: Atlantic Forest (Evergreen), Inland Forests in higher altitudes (Semideciduous and Deciduous), Riparian Forest with Carnauba, Caatingas (Hypoxerophilous, Hyperxerophilous, and Seridó), Sandbanks, and Saline Desert. Flowers and fruits: January-August, October-November.

Comments: recognized by the rachilla articulate at the base and all nodes, spikelet splitting into diaspores composed of 1 glume +1 achene + 1 rachilla internode, and rachilla wings spongy, becoming membranaceous at the margins.

Cyperus odoratus is an extremely variable Pantropical species (Tucker 1994). Such a variation was observed in the specimens collected in Rio Grande do Norte, in terms of plant height, inflorescence and spikelets. In A.A. Roque 267 (UFP), the spikelets reach over $30 \mathrm{~mm}$ long, a length not so frequent in C. odoratus, according to Tucker (1994).

18. Cyperus rotundus L., Sp. Pl.: 45. 1753.

Fig. $4 \mathrm{~h}$

Herb cespitose 11-49 cm tall. Culm 75$440 \times 0.8-2.7 \mathrm{~mm}$, trigonous, transverse septa absent, glabrous, smooth. Leaf blade present, membranaceous, green. Bracts of $1^{\text {st }}$ order 3-4, 10-65 $\times$ 0.7-3.8 mm. Inflorescence 3.5-11 $\times 3.5-9 \mathrm{~cm}$, in 2 orders: antelodium in the $1^{\mathrm{st}}$ order; spike in the ultimate order. Rachis 1.8-6 $\mathrm{mm}$ long, apparent. Spikelets $10-25 \times 1.2-1.9$ $\mathrm{mm}, 0.6-0.7 \mathrm{~mm}$ thick. Rachilla non-articulate, spikelet persistent, internodes $0.9-1.4 \mathrm{~mm}$ long. Rachilla wings present, $0.3-0.4 \mathrm{~mm}$ wide, membranaceous, hyaline. Glumes 11-28, 2.7-3.8 $\times 1.5-2.6 \mathrm{~mm}$, persistent, unicarinate, medially 5-9-nervate (including carina), vinaceous, rarely brown-vinaceous at the margins, green at the carina, glabrous, muticous or mucronate; mucron up to $0.1 \mathrm{~mm}$ long, straight. Stamina 3; anther $1.2-1.8 \times 0.15-0.2 \mathrm{~mm}$; connective prolongation absent or present at the anther apex, up to 0.1 $\mathrm{mm}$ long, reddish to vinaceous, glabrous. Achene $1.4-1.6 \times 0.7-0.8 \mathrm{~mm}, 0.5-0.6 \mathrm{~mm}$ thick, obovoid, sometimes ellipsoidal or ovoid, with a mucron 0.1 $\mathrm{mm}$ long.

Material examined: Governador Dix-Sept Rosado, Sítio Pedrinha, margem do Rio Apodi-Mossoró, 5¹9'47" S, 37'27'42" W, 22.II.2008, fl. , A.R.O. Ribeiro et al. 115 (MOSS); Mossoró, margem de lago, próximo à Feira do Bode, próximo ao Rio Apodi-Mossoró, 5¹1'58" S, 37¹9'31" W, 28.III.2008, fl., A.R.O. Ribeiro 131 (MOSS); 21.V.2008, fl. e fr., A.R.O. Ribeiro 161 (MOSS); Mossoró, margem do Rio Apodi-Mossoró, próx. ao Cartódromo, 5¹1'56" S, 37019'42" W, 24.IV.2008, fl., A.R.O. Ribeiro \& A.M.S. Araújo 143 (EAC, MOSS); Mossoró, próximo à Ponte de Ferro, Rio Mossoró, 5 11 '15' S, 37²0'39' W, 11.I.2008, fl., A.R.O. Ribeiro \& A.S. Silva 95 (MOSS); 11.V.1981, fl., O.F. Oliveira et al. 856 (MOSS); Natal, Campus Universitário da UFRN, 11.IV.2005, fl., R.M. Soares 22 (UFRN, MOSS).

Geographical distribution and phenology: Always associated with the impact of human agricultural activities in areas of Evergreen Forest, Riparian Forest with Carnauba, and Hyperxerophilous Caatinga. Flowers and fruits: January-May.

Comments: recognized by the rachis $1.8-6$ $\mathrm{mm}$ long, apparent; spikelets $10-25 \times 1.2-1.9$ $\mathrm{mm}$, persistent; glumes 2.7-3.8 × 1.5-2.6 mm, muticous or mucronate, persistent, vinaceous, rarely brown-vinaceous at the margins, green at the carina. Achenes are rarely present in the examined materials.

It has been cited as a weed in connection with at least 52 crop species in more than 90 countries (Bendixen \& Nandihalli 1987). However, despite its negative effects being relevant to agriculture, many phytotherapeutic properties of $C$. rotundus were validated by recent studies (Sivapalan 2013). Distinct phytochemicals constitute biologically active principles can be extracted from the rhizomes, tubers, leaves and roots, for example, essential oils, alkaloids, flavonoids, tannins, 
starch and sesquiterpenes (Sivapalan 2013), compounds known to have analgesic, antidiabetic, antidiarrheic, anti-inflammatory, antimicrobial, antimutagenic, antioxidant, antipyretic and/or cytoprotective activities (Ahmad et al. 2012; Jahan et al. 2012; Sivapalan 2013).

19. Cyperus schomburgkianus Nees, J. Bot. (Hooker) 2: 393. 1840.

Fig. 3e-g

Herb cespitose $15.5-30 \mathrm{~cm}$ tall. Culm $150-290 \times 0.4-1.1 \mathrm{~mm}$, trigonous, transverse septa absent, glabrous, smooth. Leaf blade present, membranaceous, green. Bracts of $1^{\text {st }}$ order $2-3$, $12-150 \times 0.7-1.8 \mathrm{~mm}$. Inflorescence $0.8-1.1 \times$ $0.8-1.3 \mathrm{~cm}$, in 1 order: glomerule spherical to hemispherical. Rachis $0.7-1.2 \mathrm{~mm}$ long, hidden by spikelets. Spikelets $2.8-7 \times 1.8-3 \mathrm{~mm}, 0.4-0.5$ $\mathrm{mm}$ thick. Rachilla non-articulate, spikelet persistent, internodes $0.2-0.3 \mathrm{~mm}$ long. Rachilla wings absent, rarely present, up to $0.1 \mathrm{~mm}$ wide, membranaceous, hyaline to ferruginous. Glumes 8-14, 2.3-2.8 $\times 0.6-1 \mathrm{~mm}$, deciduous, unicarinate, medially 5-7-nervate (including carina), margins and carina white, brown when dried, glabrous, muticous, rarely mucronate; mucron up to $0.1 \mathrm{~mm}$ long, straight. Stamina 3; anther 1-1.1 $\times 0.1-0.15$ $\mathrm{mm}$; connective prolongation absent or present at the anther apex, up to $0.1 \mathrm{~mm}$ long, ferruginous to vinaceous, glabrous. Achene $0.9-1 \times 0.2-0.3$ $\mathrm{mm}, 0.2-0.3 \mathrm{~mm}$ thick, oblanceoloid to oblongoblanceoloid, with a mucron $0.1 \mathrm{~mm}$ long.

Material examined: Caicó, Sítio Pelados, Serra de São Bernardo, 14.III.2009, fl., A.A. Roque 661 (UFRN); Jucurutu, RPPN Stoessel de Britto, 29.III.2008, fl., A.A. Roque 502 (UFRN, MOSS); Serra Negra do Norte, Estação Ecológica do Seridó (ESEC), Campo de Jurema, Estrada do Junco, 6 $636^{\prime} 18^{\prime \prime} \mathrm{S}, 37^{\circ} 15^{\prime} 02^{\prime \prime} \mathrm{W}$, 16.IV.2006, fl., R.T. Queiroz 718 (UFRN); 11.IV.2006, fl., C.G.T. Ferreira \& V.A.O. Oliveira Irmão 25 (MOSS); 20.V.2006, fl. e fr., R.C. Oliveira \& C.G.T. Ferreira 1645 (MOSS).

Geographical distribution and phenology: restricted to the Caatingas (Hyperxerophilous and Seridó). Flowers and fruits: March-May.

Comments: recognized by the inflorescence in a single order with glomerules white, solitary; glumes $2.3-2.8 \times 0.6-1 \mathrm{~mm}$, unicarinate. The glomerules turn brown after being dried.

20. Cyperus sphacelatus Rottb., Descr. Icon. Rar. $\mathrm{Pl} .: 26.1773$.

Fig. $4 \mathrm{i}$

Herb cespitose $18-35.5 \mathrm{~cm}$ tall. Culm $140-285 \times 1.2-2.2 \mathrm{~mm}$, trigonous, transverse septa absent, glabrous, smooth. Leaf blade present, membranaceous, green. Bracts of $1^{\text {st }}$ order 5-7, $8-120 \times 0.5-4.7 \mathrm{~mm}$. Inflorescence $2.5-6 \times$ $3-6.5 \mathrm{~cm}$, in $2-3$ orders: antelodium in the $1^{\text {st }}$ order; antelodium or spike in the $2^{\text {nd }}$ order; spike in the ultimate order. Rachis (1.5) $2-9 \mathrm{~mm}$ long, apparent. Spikelets 7-15 × 1.3-2 mm, 0.6-0.8 mm thick. Rachilla non-articulate, spikelet persistent, internodes $0.7-0.9 \mathrm{~mm}$ long. Rachilla wings present, $0.3-0.4 \mathrm{~mm}$ wide, membranaceous, hyaline. Glumes 9-18, 2.4-2.8 × 1.6-2 mm, deciduous, unicarinate, medially 5-9-nervate (including carina), brown with an area vinaceousmaculate at the margins forming a longitudinal vinaceous line at the center of each lateral side of the spikelet, rarely the margins entirely brown, green to brown at the carina, glabrous, muticous or mucronate; mucron up to $0.2 \mathrm{~mm}$ long, straight. Stamina 3; anther 0.4-0.6 × 0.1-0.15 $\mathrm{mm}$; connective prolongation absent or present at the anther apex, up to $0.1 \mathrm{~mm}$ long, hyaline to ferruginous, glabrous. Achene $1-1.2 \times 0.6-0.7 \mathrm{~mm}$, $0.5-0.6 \mathrm{~mm}$ thick, obovoid, ellipsoidal or ovoid, with a mucron $0.1 \mathrm{~mm}$ long.

Material examined: Natal, Genipabú, 3.VIII.1994, fl. e fr., M. Luceño 209 (UFP); Natal, Genipabú, aos Arredores do Alagado próx. ao Acesso da Praia, 8.XI.1996, fl. e fr., A.P. Mendes \& A.C. Settini 404 (UFP); Natal, Lagoa do Guamoré, 5०42'37" S, 3515'44" W, 4.XI.2007, fl. e fr., A.R.O. Ribeiro et al. 69 (EAC, MOSS).

Geographical distribution and phenology: restricted to the Sandbanks at the humid eastern coast. Flowers and fruits: August, November.

Comments: recognized by the spikelets brown or greenish, ornate with a longitudinal vinaceous line at the center of each lateral side, rarely entirely brown or greenish, glumes $2.4-2.8$ $\times 1.6-2 \mathrm{~mm}$, and achenes $1-1.2 \times 0.6-0.7 \mathrm{~mm}$.

The specimen A.P. Mendes \& A.C. Settini 404 has the margins of the some glumes entirely brown, thus the spikelet is devoid of the above mentioned vinaceous line.

21. Cyperus squarrosus L., Cent. Pl. II: 6. 1756.

Fig. $3 \mathrm{~h}$

Herb cespitose $6-31 \mathrm{~cm}$ tall. Culm 30 $250 \times 0.5-1.6 \mathrm{~mm}$, trigonous, transverse septa absent, glabrous, smooth. Leaf blade present, membranaceous, green. Bracts of $1^{\text {st }}$ order $2-5$, $9-100 \times 0.5-3 \mathrm{~mm}$. Inflorescence $1.2-5 \times 1.1-5$ $\mathrm{cm}$, in 2 orders: antelodium in the $1^{\mathrm{st}}$ order; spike in the ultimate order. Rachis 1-8 mm long, apparent or hidden by spikelets. Spikelets $2-6.5 \times 0.8-1.7$ 
$\mathrm{mm}, 0.2-0.4 \mathrm{~mm}$ thick. Rachilla articulate at the base, spikelet falling as a unity, internodes 0.3-0.4 $\mathrm{mm}$ long. Rachilla wings absent, rarely present, up to $0.1 \mathrm{~mm}$ wide, membranaceous, hyaline to vinaceous. Glumes 5-15, 1.2-1.8 × 0.6-0.8 mm, persistent, unicarinate, medially 7-9-nervate (including carina), greenish, brown, orange to vinaceous at the margins and carina, glabrous, aristate; arista $0.5-1.6 \mathrm{~mm}$ long, recurvate $45-100^{\circ}$. Stamen 1; anther $0.2-0.3 \times 0.1 \mathrm{~mm}$; connective prolongation absent or present at the anther apex, up to $0.1 \mathrm{~mm}$ long, hyaline to ferruginous, glabrous. Achene $0.7-0.8 \times 0.2-0.3 \mathrm{~mm}, 0.2-0.3 \mathrm{~mm}$ thick, lanceoloid, obovoid or oblong-obovoid, with a mucron $0.1 \mathrm{~mm}$ long.

Material examined selected: Caicó, Sítio Pelados, 23.V.2009, fl. e fr., J.L.C. Lima \& A.A. Roque 161 (UFRN); Campo Redondo, Fazenda Giromão, 5.VIII.2009, fl. e fr., A.A. Roque 1055 (UFRN); Felipe Guerra, Cachoeira do Roncador, próximo ao Rio Apodi-Mossoró, 5³4'35' S, 37\%40'33" W, 26.IV.2008, fl. e fr., A.R.O. Ribeiro et al. 152 (MOSS); Luís Gomes, Tigre de Cima, nascente do Rio Apodi-Mossoró, 6²1'26” S, 38²7'42'”, 30.V.2008, fl. e fr., A.R.O. Ribeiro et al. 204 (MOSS); Mossoró, margem do Rio Apodi-Mossoró, próximo ao Cartódromo, 5¹1'56" S, 37¹9'42"W, 24.IV.2008, fl. e fr., A.R.O. Ribeiro \& A.M.S. Araújo 147 (MOSS); Santo Antônio, 1 km após o povoado de Lagoa Limpa, em direção a Santo Antônio, 6²5'47" S, 35²6'84" W, 14.V.2009, fl. e fr., R.C. Oliveira et al. 2407 (MOSS); São Paulo do Potengi, 4 km após o trevo Riachuelo-São Paulo do Potengi., 5'52'42" S, 3545'77'W, 14.V.2009, fl. e fr., R.C. Oliveira et al. 2369 (MOSS); Serra Negra do Norte, Estação Ecológica do Seridó, afloramento, 634'04' S, 37015'98' W, 14.IV.2006, fl. e fr., R.T. Queiroz 668 (HUEFS, UFP, UFRN).

Geographical distribution and phenology: registered in the inland areas of the state, border of the Inland Forests in higher altitudes (Deciduous), Riparian Forest with Carnauba, Caatingas (Hypoxerophilous, Hyperxerophilous, and Seridó), and Saline Desert. Flowers and fruits: April-June, August.

Comments: can be confused with $C$. cuspidatus (v. comments under this species). It has a peculiar odor (resembling papaya fruits, Carica papaya L.), which remains even in dried specimens, and also reported by Costa (2013). Tucker (1994) indicates it persists in its type specimen collected in Mexico in 1841.

22. Cyperus surinamensis Rottb., Descr. Icon. Rar. P1.: 35. 1773.

Fig. 2k

Herb cespitose 29.5-108 cm tall. Culm 250-910 × 1.6-5 mm, trigonous, transverse septa absent, glabrous, retrorsely scabrous to smooth at the basal and medial portions, but retrorsely scabrous, rarely smooth at the apical portion. Leaf blade present, membranaceous, green. Bracts of $1^{\text {st }}$ order 4-7, 10-330 × 1.2-6 mm. Inflorescence 2.5-12 × 1.8-17 cm, in 3-5 orders: antelodium in the $1^{\text {st }}$ order; antelodium or glomerule in the $2^{\text {nd }}$ order; antelodium, glomerule or serial fascicle in the $3^{\text {rd }}$ order; glomerule or serial fascicle in the $4^{\text {th }}$ order; serial fascicle in the ultimate order. Rachis $0.3-0.5 \mathrm{~mm}$ long, apparent or hidden by spikelets. Spikelets 3-12 × 1.5-2.4 mm, 0.2-0.3 mm thick. Rachilla non-articulate, spikelet persistent, internodes $0.2-0.3 \mathrm{~mm}$ long. Rachilla wings absent or present, up to $0.1 \mathrm{~mm}$ wide, membranaceous, hyaline to ferruginous. Glumes $13-36,1.2-1.5$ $\times 0.8-1.1 \mathrm{~mm}$, deciduous, bicarinate, medially 2-3-nervate (including carinas), greenish-brown, yellowish to orange at the margins and carina, glabrous, muticous or mucronate; mucron up to $0.1 \mathrm{~mm}$ long, straight. Stamen 1; anther 0.4-0.6 $\times 0.1-0.15 \mathrm{~mm}$; connective prolongation present at the anther apex, $0.1-0.15 \mathrm{~mm}$ long, orange to vinaceous, glabrous. Achene $0.6-0.8 \times 0.2-0.4 \mathrm{~mm}$, $0.2-0.3 \mathrm{~mm}$ thick, ovoid to lanceoloid, ellipsoidal to narrowly ellipsoidal, obovoid to oblanceoloid, with a mucron $0.1 \mathrm{~mm}$ long.

Material examined selected: Caicó, RN 288, sentido Currais Novos, entrada ca. $1 \mathrm{~km}$ da cidade, vicinal para a Serra da Formiga, $5 \mathrm{~km}$ da entrada, área com inundação, 6 6 $25^{\prime} 06^{\prime}$ ' S, 37 03 ' $17^{\prime}$ ' W, 15.VIII.2009, fl. e fr., J.G. Jardim et al. 5479 (UFRN); Canguaretama, Barra do Cunhaú, cerca de $3 \mathrm{~km}, 6^{\circ} 19^{\prime} 43^{\prime}$ ' S, 3503'44", W, 3.XI.2007, fl. e fr., A.R.O. Ribeiro et al. 52 (EAC, MOSS); Luís Gomes, estrada para Cachoeira do Rela, próximo ao cumaru com Tillandsia, margem de afluente do Rio Apodi-Mossoró, 6²3'51' S, 38²2'52' W, 31.V.2008, fl. e fr., A.R.O. Ribeiro et al. 207 (MOSS); Luís Gomes, estrada para Tigre de Cima, margem de afluente do Rio Apodi-Mossoró, próximo a ponte da Baixa do Almeida, 6²3'53' S, 38 24'36" W, 30.V.2008, fl. e fr., A.R.O. Ribeiro et al. 214 (MOSS); Martins, açude de Portinho, 605'39' S, 3755' 57' W, 25.IV.2006, fl. e fr., M.I.B. Loiola 872 (MOSS, UFRN); Mossoró, margem de lago próximo à Feira do Bode, próximo ao Rio ApodiMossoró, 511'58" S, 37¹9'31' W, 29.I.2008, fl. e fr., A.R.O. Ribeiro 99 (MOSS); Natal, Lagoa do Guamoré, 5'42'37" S, 35'15'44"' W, 4.XI.2007, fl. e fr., A.R.O. Ribeiro et al. 68 (EAC, MOSS); Santo Antônio, $1 \mathrm{~km}$ após o povoado de Lagoa Limpa, em direção a Santo Antônio, 6²5'47" S, 35²6'84"'W, 14.V.2009, fl. e fr., R.C. Oliveira et al. 2418 (MOSS); São Paulo do Potengi, logo após o trevo São Paulo do Potengi-Senador Elói de Souza, 14.V.2009, fl. e fr., R.C. Oliveira et al. 2379 (MOSS); Serra Negra do Norte, 10.VI.1980, fl. e fr., O.F. Oliveira et al. 1007 (MOSS). 
Geographical distribution and phenology: Widely distributed: border of the Atlantic Forest (Evergreen), Inland Forests in higher altitudes (Semideciduous and Deciduous), Riparian Forest with Carnauba, Cerrado, Caatingas (Hypoxerophilous, Hyperxerophilous, and Seridó), and Sandbanks. Flowers and Fruits: January, March-August, November.

Comments: can be confused with $C$. entrerianus (v. comments under species 9). The arrangement of the spikelets, which was defined as a serial fascicle by Guarise \& Vegetti (2007), is peculiar among the species of Cyperus. In this type of inflorescence, the spikelets are distichously arranged, with the lateral sides approximately parallel, facing each other. According to Gaurise \& Vegetti (2007), the presence of serial fascicles in the inflorescence is an important distinguishing parameter among the species in Cyperus sect. Luzuloideae (Kunth) C.B. Clarke.

In A.R.O. Ribeiro et al. 207 (MOSS) there are culms slightly scabrous and smooth in the same plant, which confirms the character variation in the species as has been reported by Ribeiro et al. (2014). In O.F. Oliveira et al. 1007, the culms are smooth, even at the apex; the specimen identification was based on the presence of serial fascicles and achenes $0.6-0.8 \mathrm{~mm}$ long. In R.C. Oliveira et al. 2379, the serial fascicles are very congested into dense glomerules, which made it difficult to identify; however, the identification of the specimen was possible by the presence of culm retrorsely scabrous and achenes $0.6-0.8 \mathrm{~mm}$ long.

23. Cyperus uncinulatus Schrad. ex Nees, C.F.P. von Martius \& auct. suc. (eds.), Fl. Bras. 2(1): 23. 1842.

Fig. 3i-k

Herb cespitose $6.5-29 \mathrm{~cm}$ tall. Culm 40$260 \times 0.2-0.6 \mathrm{~mm}$, trigonous, transverse septa absent, glabrous, smooth. Leaf blade present, membranaceous, green. Bracts of $1^{\text {st }}$ order $3-5$, $6-95 \times 0.5-1.5 \mathrm{~mm}$. Inflorescence $0.5-1.2 \times$ $0.4-1.5 \mathrm{~cm}$, in 1 order composed of a glomerule spherical to hemispherical. Rachis $0.3-1 \mathrm{~mm}$ long, hidden by spikelets. Spikelets $3-7 \times 1.5-2 \mathrm{~mm}$, $0.3-0.4 \mathrm{~mm}$ thick. Rachilla non-articulate, spikelet persistent, internodes $0.2-0.3 \mathrm{~mm}$ long. Rachilla wings absent or present, up to $0.1 \mathrm{~mm}$ wide, membranaceous, hyaline, ferruginous to vinaceous. Glumes 9-36, 0.9-1.2 × 0.6-0.9 mm, deciduous, unicarinate, medially 3(5)-nervate (including carina), brown, glaucous, yellowish to ochraceous at the margins, green to brown at the carina, glabrous; mucronate to aristate; mucron/arista $0.3-0.8 \mathrm{~mm}$ long, recurvate $(22.5) 30-60^{\circ}$. Stamen 1 ; anther $0.4-0.6 \times 0.1-0.15 \mathrm{~mm}$; connective prolongation absent or present at the anther apex, up to $0.1 \mathrm{~mm}$ long, hyaline, ferruginous, reddish to vinaceous, glabrous. Achene $0.4-0.6 \times 0.2-0.4 \mathrm{~mm}$, $0.2-0.3 \mathrm{~mm}$ thick, ovoid, ellipsoidal or obovoid, with a mucron $0.1 \mathrm{~mm}$ long.

Material examined selected: Caicó, Sítio Pelados, Serra de São Bernardo, 14.III.2009, fl. e fr., A.A. Roque 670 (UFRN); Jardim do Seridó, Sítio Catururé, margens do Rio Seridó, próximo à Ponte de Zé de Bastos, 15.III.2009, fl. e fr., A.A. Roque 705 (UFRN); Jucurutu, RPPN Stoessel de Britto, 9.III.2008, fl. e fr., A.A. Roque 489 (UFRN, MOSS); Mossoró, Fazenda Sussuarana, 5'11'15" S, 37²0'39" W, 17.III.2007, fl. e fr., R.C. Oliveira et al. 1921 (MOSS); Sanatana do Matos, 28.II.1980, fl. e fr., O.F. Oliveira et al. 72 (MOSS); 17.V.1981, fl. e fr., O.F. Oliveira et al. 1781 (MOSS); São Tomé, 14.IV.1980, fl. e fr., O.F. Oliveira et al. 290 (MOSS); O.F. Oliveira et al. 291 (MOSS); Serra Negra do Norte, Estação Ecológica do Seridó (ESEC), bosque

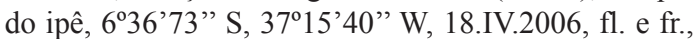
R.T. Queiroz 767 (HUEFS, UFRN).

Geographical distribution and phenology: registered in areas of Caatinga (Hypoxerophilous, Hyperxerophilous, and Seridó) and Riparian Forest with Carnauba. Flowers and fruits: February-June.

Comments: can be confused with $C$. cuspidatus (v. comments under this species).

\section{Cyperus sp. 1}

Fig. 5h-k

Herb cespitose 90-114 cm tall. Culm $740-935 \times 3.9-4.5 \mathrm{~mm}$, trigonous, transverse septa absent, glabrous, papillose. Leaf blade present, chartaceous, glaucous. Bracts of $1^{\text {st }}$ order $8-9,23-755 \times 1.3-11 \mathrm{~mm}$. Inflorescence 18-20 $\times 21-24 \mathrm{~cm}$, in 3 orders: antelodium in the $1^{\text {st }}$ order; antelodium or spike in the $2^{\text {nd }}$ order; spike in the ultimate order. Spikelets $6-14 \times 1-1.8 \mathrm{~mm}$, $0.6-0.8 \mathrm{~mm}$ thick. Rachilla articulate at the base, spikelet falling as a unity, internodes $0.9-1.2 \mathrm{~mm}$ long. Rachilla wings present, $0.4-0.6 \mathrm{~mm}$ wide, membranaceous, hyaline to greenish-hyaline. Glumes (5)7-11, 2.7-3 × 1.4-1.6 mm, persistent, unicarinate, medially 9-11-nervate (including carina), vinaceous to brown at the margins, green at the carina, glabrous; muticous or mucronate; mucron up to $0.2 \mathrm{~mm}$ long, straight. Stamina 3 ; anther $0.5-0.7 \times 0.1-0.15 \mathrm{~mm}$; connective prolongation absent or present at the anther apex, up to $0.1 \mathrm{~mm}$ long, reddish to vinaceous, glabrous. 


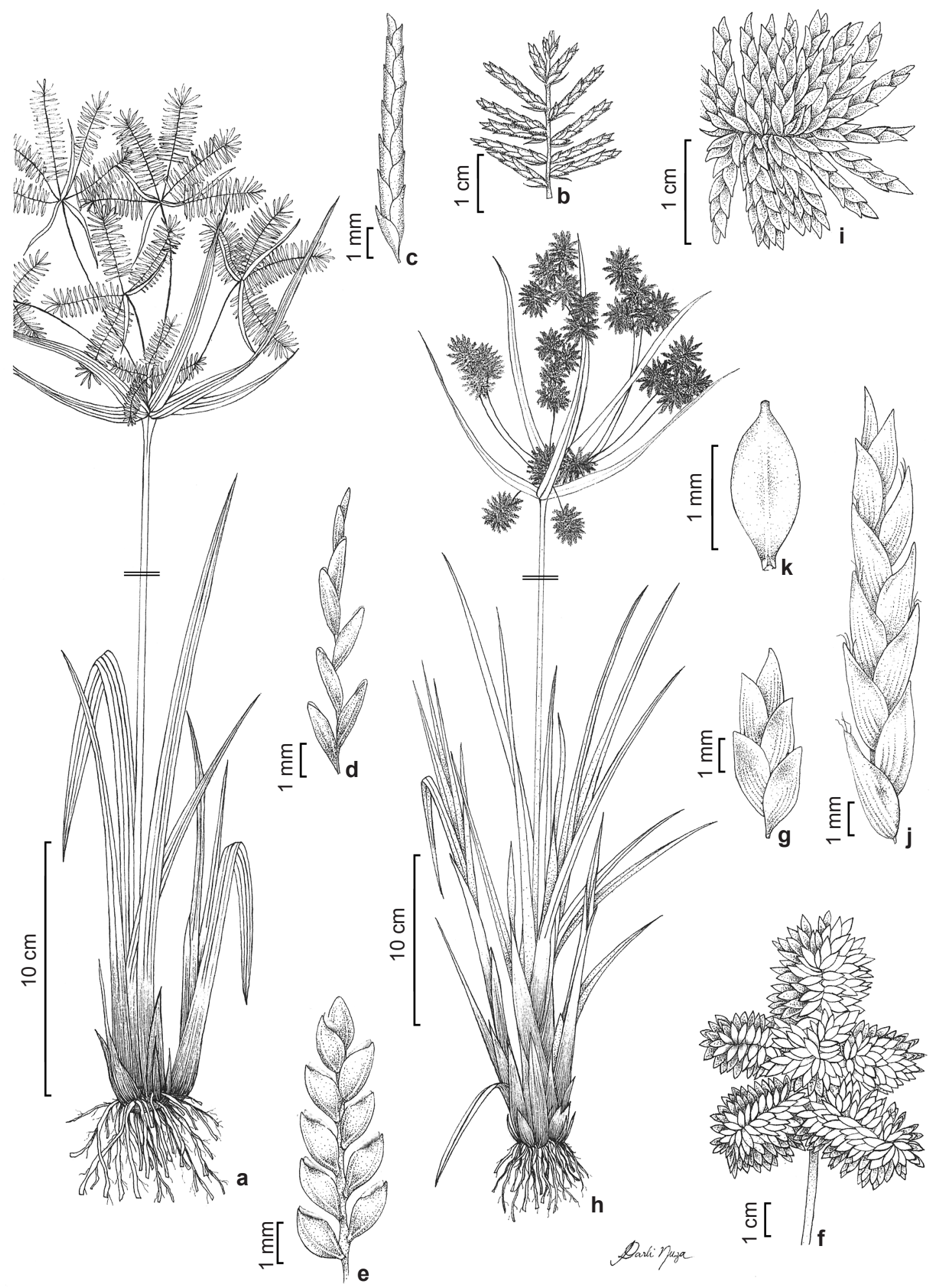

Figure 5 - a-c. Cyperus digitatus - a. habit; b. spike; c. spikelet. d. C. distans - spikelet. e. C. iria - spikelet. f-g. C. ligularis - f. spike; g. spikelet. h-k. Cyperus sp. 1 - h. habit; i. spike; j. spikelet; k. achene (a-c A.A. Roque 417; d A.R.O. Ribeiro et al. 177; e A.R.O. Ribeiro 160; f-g A.R.O. Ribeiro 19; h-k A.R.O. Ribeiro et al. 247). 
Achene 1.4-1.6 × 0.6-0.7 mm, 0.6-0.7 mm thick, ovoid to lanceoloid, ellipsoidal or obovoid, with a mucron $0.1 \mathrm{~mm}$ long.

Material examined: Campo Redondo, Fazenda Giromão, 5.VIII.2009, fl. e fr., A.A. Roque 1051 (UFRN); Equador, 14.IV.1981, fl. e fr., G.F.C. Lima 132 (MOSS); Jucurutu, Serra João do Vale, 06 00 '43”S, 3708'52”W, 29.V.2010, fl. e fr., A.R.O. Ribeiro et al. 247 (UB, MOSS, RB); São Paulo do Potengi, logo após o trevo São Paulo do Potengi-Senador Elói de Souza, 14.V.2009, fl. e fr., R.C. Oliveira et al. 2381 (MOSS).

Geographical distribution and phenology: restricted to the Caatingas (Hypoxerophilous, Hyperxerophilous, and Seridó). Flowers and fruits: April-May, August.

Comments: It is a species related to Cyperus sect. Turgiduli (C.B. Clarke) Kük., since the spikelets are articulate at the base and falling entire at maturity, the rachilla largely winged, and the glumes appressed.

Among the species in the section Turgiduli, only C. alvesii G.C. Tucker, C. javanicus Houtt. and $C$. ligularis combine papillose culms and leaf blades, inflorescences of the compound antelodium type, and spikelets longer than $5 \mathrm{~mm}$ (Kükenthal 1936; Tucker 2008), but $C$. javanicus does not grow in Neotropics (Tucker 2008).

Cyperus sp. 1 can be distinguished from $C$. ligularis by the spikelets, glumes, and rachilla internodes (v. comments under this species) and from C. alvesii by the spikelets, glumes, and anthers. In $C$. alvesii, which is known to occur only in the states of Paraíba and Bahia, the spikelets have 3-(4) glumes (vs. (5)7-11 in Cyperus sp. 1), the rachilla internodes are 2-2.2 mm long (vs. 0.9-1.2 mm in Cyperus sp. 1), the glumes are $3.2-4 \mathrm{~mm}$ long (vs. $2.7-3 \mathrm{~mm}$ in Cyperus sp. 1), and the anthers are (1.3)1.6-1.8 mm long (vs. 0.5-0.7 mm in Cyperus sp. 1).

Some specimens were misidentified as C. pohlii (Nees) Steud., but the analyzis of the typus specimens belonging to this species showed leaves non-pappilose, green and M-shaped in cross section. These morphological characters are incompatible with specimens here examined.

\section{Acknowledgements}

This work was supported by CAPES, CNPq

- Protax Program (Process 562340/2010-6), Petrobrás Ambiental, UFERSA and UnB. We thank the curators and staff of the herbaria EAC, HUEFS, UFP and UFRN for loans of exsiccatae. We are sincerely grateful to Anádria Stéphanie da Silva, Antônia Kátia Pinheiro de Medeiros, Caio César
Pereira Leal, José Erivaldo de Araújo, Prof. Maiele Leandro da Silva, and Suzi Helena de Santana for their support during the preparation of specimens and botanical expeditions, and Kadja Milena for providing photos of the type of C. crassipes.

\section{References}

Adams, C.D. 1994. Cyperus (Cyperaceae). In: Davidse, G.; Souza, M.S. \& Chater, A.O. (eds.). Flora Mesoamericana. Vol. 6. Universidad Nacional Autónoma de México, México-DF. Pp. 404-422.

Ahmad, M.; Mahayrookh; Mehjabeen; Rehman, A.B. \& Jahan, N. 2012. Analgesic, antimicrobial and cytotoxic effect of Cyperus rotundus ethanol extract. Pakistan Journal of Pharmacology 29: 7-13.

Almeida Júnior, E.B. \& Zickel, C.S. 2009. Fisionomia psamófila-reptante: riqueza e composição de espécies na praia da pipa, Rio Grande do Norte, Brasil. Pesquisas, Botânica 60: 289-299.

Alves, M. \& Martins, S. 2009. Cyperaceae. In: Alves, M.; Araújo, M.F.; Maciel, J.R. \& Martins, S. (orgs.). Flora de Mirandiba. Vol. 1. Associação Plantas do Nordeste, Recife. Pp. 137-145.

Alves, M.; Hefler, S.M.; Trevisan, R.; Silva Filho, P.J.S.; Ribeiro, A.R.O. 2014. Cyperaceae In: Lista de Espécies da Flora do Brasil. Jardim Botânico do Rio de Janeiro. Available at $<$ http://floradobrasil. jbrj.gov.br/jabot/floradobrasil/FB100>. Access on 18 August 2014.

Araújo, A.C. \& Longhi-Wagner, H.M. 1996. Levantamento taxonômico de Cyperus L. subg. Anosporum (Nees) C.B. Clarke (Cyperaceae Cypereae) no Rio Grande do Sul, Brasil. Acta Botanica Brasilica 10: 153-192.

Bendixen, L.E. \& Nandihalli, U.B. 1987. Worldwide Distribution of Purple and Yellow Nutsedge (Cyperus rotundus and C. esculentus). Weed Technology 1: 61-65.

Costa, S.M. 2013. Cyperus L. (Cyperaceae) In: Prata, A.P.N.; Amaral, M.C.E.; Farias, M.C.V.; Alves, M.V. (orgs.). Flora de Sergipe. Vol. 1. Triunfo, Aracaju, Pp. 140-158.

CRIA. 2014. Rede SpeciesLink. Available at $<$ http:// www.splink.org.br/index?lang=pt $>$. Access on 14 September 2014.

Denton, M.F. 1978. Taxonomic treatment of the "Luzulae" group of Cyperus. Taxonomic treatment of the "Luzulae" group of Cyperus. Contributions from the University of Michigan Herbarium 11: 197-271.

Goetghebeur, P. 1998. Cyperaceae. In: K. Kubitzki (ed.). The families and genera of vascular plant: IV. Flowering plants - monocotyledons. SpringerVerlag, Berlin. Pp. 141-190.

Govaertz, R.; Simpson, D.A.; Goetghebeur, P.; Wilson, K.L.; Egorova, T. \& Bruhl, J. 2014. World Checklist of Cyperaceae. The Board of Trustees of the Royal 
Botanic Gardens, Kew. Available at $<$ http://www. kew.org/wcsp/monocots/>. Access on 17 July 2014.

Guarise, N.J. \& Vegetti, A.C. 2007. Inflorescences structure of Cyperus L. section Luzuloidei Kunth (Cyperaceae). Plant Systematics and Evolution 271: 41-63.

Haines, R.W. \& Lye, K.A. 1983. The sedges and rushes of East Africa: A flora of the families Juncaceae and Cyperaceae in East Africa - with a particular reference to Uganda. East African National History Society, Nairobi. 404p.

Hefler, S.M. \& Longhi-Wagner, H.M. 2012. Cyperus L. subg. Cyperus (Cyperaceae) na Região Sul do Brasil. Revista Brasileira de Biociências 10: 327-372.

Henry-Silva, G.G.; Moura, R.S.T. \& Dantas, L.L.O. 2010. Richness and distribution of aquatic macrophytes in Brazilian semi-arid aquatic ecosystems. Acta Limnologica Brasiliensia 22: 147-156.

IDEMA. 2007. Estado do Rio Grande do Norte: esboço da vegetação. Available at $<$ http://www.portal. rn.gov.br/contentproducao/aplicacao/idema/ anuario/anteriores/anuario2008/caracterizacao_ territorio.html>. Access on 5 April 2008.

Jahan, N.; Rahman, K.U. \& Ali, S. 2012. Cardioprotective and antilipidemic potential of Cyperus rotundus in chemically induced cardiotoxicity. International Journal of Agriculture and Biology 14: 989-992.

Kükenthal, G. 1936. Cyperaceae Scirpoideae, Cypereae. In: ENGLER A. (ed.). Das Pflanzenreich: Reigni Vegetabilis Conspectus. H. R. Hengelmann, Weinheim. Vol 4, n. 20, pp. 1-621.

Larridon, I.; Huygh, W.; Reynders, M.; Muasya, A.M.; Govaerts, R.; Simpson D.A. \& Goetghebeur, P. 2011a. Nomenclature and typification of names of genera and subdivisions of genera in Cypereae (Cyperaceae): 2. Names of subdivisions in Cyperus. Taxon 60: 868-884.

Larridon, I.; Reynders, M.; Huygh, W.; Bauters, K.; Van de Putte, K.; Muasya, A.M.; Boeckx, P.; Simpson, D.A.; Vrijdaghs, A. \& Goetghebeur, P. 2011 b. Affinities in C3 Cyperus lineages (Cyperaceae) revealed using molecular phylogenetic data and carbon isotope analysis. Botanical Journal of the Linnean Society 167: 19-46.

Larridon, I.; Reynders, M.; Huygh, W.; Bauters, K.; Vrijdaghs, A.; Leroux, O.; Muasya, A.M. \& Goetghebeur, P. 2011c. Taxonomic changes in C3 Cyperus (Cyperaceae) supported by molecular phylogenetic data, morphology, embryography, ontogeny and anatomy. Plant Ecology and Evolution 144: 327-356.

Larridon, I.; Bauters, K.; Reynders, M.; Huygh, W.; Muasya, A.M.; Simpson, D.A. \& Goetghebeur, P. 2013. Towards a new classification of the giant paraphyletic genus Cyperus. Botanical Journal of the Linnean Society 172: 106-126.
Luceño, M.; Alves, M.V. \& Mendes, A.P.N. 1997. Catálogo florístico y claves de identificación de las ciperáceas de los Estados de Paraíba y Pernambuco (nordeste de Brasil). Anales del Jardín Botánico de Madrid 55: 67-100.

Martins, S.; Machado, S.R. \& Alves, M. 2008. Anatomia e ultra-estrutura foliar de Cyperus maritimus Poir. (Cyperaceae): estratégias adaptativas ao ambiente de dunas litorâneas. Acta Botanica Brasilica 22: 493-503.

Muasya, A.M.; Simpson, D.A.; Verboom, G.A.; Goetghebeur, P.; Naczi, R.F.C.; Chase, M.W. \& Smets, E. 2009a. Phylogeny of Cyperaceae based on DNA sequence data: current progress and future prospects. Botanical Review 75: 2-21.

Muasya, A.M.; Vrijdaghs, A.; Simpson, D.A.; Chase, M.W.; Goetghebeur, P. \& Smets, E. 2009b. What is a genus in Cypereae: phylogeny, character homology assessment and generic circumscription in Cypereae. Botanical Review 75: 52-66.

Oliveira, R.C.; Silva, A.S.; Ribeiro, A.R.O.; Araújo J.E.; Oliveira O.F. \& Camacho, R.G.V. 2013. List of Angiosperm species of the riparian vegetation of the Apodi-Mossoró river, Rio Grande do Norte, Brazil. Check List 9: 740-751.

Radford, A.E.; Dickison, W.C.; Massey, J.R. \& Bell, C.R. 1974. Vascular Plants Systematics. Harper e How, New York. 891p.

Ribeiro, A.R.O.; Prata, A.P.N.; Camacho R.G.V.; Oliveira, O.F. \& Oliveira, R.C. 2014. Cyperaceae do rio Apodi-Mossoró, Estado do Rio Grande do Norte, Brasil. Hoehnea 41: 149-171.

Simpson, D.A.; Muasya, A.M.; Alves, M.; Bruhl, J.J.; Dhooge, S.; Chase, M.W.; Furness, C.A.; Ghamkhar, K.; Goetghebeur, P.; Hodkinson, T.R.; Marchant, A.D.; Nieuborg, R.; Reznicek, A.A.; Roalson, E.H.; Smets, E.; Starr, J.R., Thomas, W.W.; Wilson, K.L. \& Zhang, X. 2007. Phylogeny of Cyperaceae based on DNA sequence data - a new rbcL analysis. Aliso 23: 72-83.

Sivapalan, S.R. 2013. Medicinal uses and Pharmacological activities of Cyperus rotundus Linn. - A Review. International Journal of Scientific and Research Publications 3: 1-8.

Thiers, B. [Continuously updated]. Index Herbariorum: A global directory of public herbaria and associated staff. New York Botanical Garden's Virtual Herbarium. Available at $<\mathrm{http}: / /$ sweetgum.nybg. org/ih/>. Access on 5 April 2014.

Tucker, G.C. 1983. The taxonomy of Cyperus (Cyperaceae) in Costa Rica and Panama. Systematic Botany Monographs 2: 1-85.

Tucker, G.C. 1994. Revision of the Mexican species of Cyperus (Cyperaceae). Systematic Botany Monographs 43: 1-213.

Tucker, G.C. 2008. Cyperus alvesii (Cyperaceae), a new species from northeastern Brazil. Harvard Papers in Botany 13: 237-240. 
Exsiccatae list:

Aldesandro L. 9 - MOSS (17), Alunos da turma de pós-graduação 2005.1 s.n. - MOSS 11744, UFRN 2194 (5), Alunos do Curso de Botânica I s.n. - MOSS 3662 (17), Alunos do Curso de Botânica I s.n. - MOSS 3663 (22), Alves M. \& Heald S. s.n. - UFP 44400 (5), Amaral A. 2 - MOSS (5), Araújo Junior M. s.n. - MOSS 5569 (12), Carvalho H.N. s.n. - MOSS 305 (21), Cavalcante E.A.A. s.n. - MOSS 10153 (15), Cestaro L.A. 97-0021 - UFRN (12), Costa R.A. \& Marinho A.M. 51 - MOSS, UFRN (15), Costa-Lima J.L. et al. 258 - UFRN (9), Cunha E.M. \& Calistrato E.P.N. 6 - MOSS (15), Dantas A. et al. 168 - UFRN (22), de Lima M.E.G. \& Alves M.Z. 7 - MOSS (9), Duarte F.S. et al. 7 - MOSS (17), Ernesto Sobrinho F. 5 - MOSS (22), Fernandes A. et al. 110 - MOSS (23), Fernandes A. et al. 99 - MOSS (17), Ferreira C.G.T. \& Oliveira Irmão V.A.O. 25 - MOSS (19), Ferreira C.G.T. \& Oliveira R.C. 8 - MOSS (23), Ferreira C.G.T. \& Silva S.V.O. 126 - MOSS (3), Ferreira C.G.T. \& Silva S.V.O. 97 - EAC, MOSS (3), Filho E. et al. 4 - MOSS (15), Fontenele J.A. 10 - MOSS (12), Forte F.A. de F. 2 - MOSS (1), Gonçalves Junior B. et al. s.n. - MOSS 3733, MOSS 3735 (3), Gurgel F.L. 4 - MOSS (5), Jardim J.G. \& Ganade M.G. 5597 - UFRN (5), Jardim J.G. et al. 5479 - UFRN (22), Jardim J.G. et al. 5537 - UFRN (15), José M. et al. s.n. MOSS 5356 (2), Leal L. s.n. - MOSS (17), Lima A.R. s.n. - MOSS 270 (4), Lima G.F.C. 10 - MOSS (23), Lima G.F.C. 132 - MOSS (24), Lima J.L.C. \& Roque A.A. 161 - UFRN (21), Lima J.L.C. 40 - UFRN (5), Loiola I. 862 - UFRN (17), Loiola I. 866 - MOSS (5), Loiola I. et al. s.n. - MOSS 11741 (12), Loiola M.I.B. \& Loiola M.A. 973 - UFRN, MOSS (5), Loiola M.I.B. \& Queiroz R.T. 877 - UFRN (8), Loiola M.I.B. 1260 - UFRN (5), Loiola M.I.B. 871 - MOSS, UFRN (1), Loiola M.I.B. 872 - MOSS, UFRN (22), Loiola M.I.B. 878 - MOSS, UFRN (15), Lopes P.A.R. et al. 26 - MOSS (2), Luceño M. 201 - UFP (5), Luceño M. 209 - UFP (20), Luceño M. 210 - UFP (4), Luceño M. 224 - UFP (12), Luceño M. 225 - UFP (5), Luceño M. 233 - UFP (11), Luceño M. 354 - UFP (2), Luceño M. 355 - UFP (12), Marinho A.M. \& Marinho A.L.M. 44 - MOSS (1), Marinho A.M. 63 - MOSS (5), Martins S. \& Alves M. 226 - HUEFS, UFP (5), Martins S. \& Alves M. 227 - UFP (8), Martins S. \& Alves M. 228 - UFP (13), Martins S. \& Alves M. 229 - UFP (4), Martins S. \& Alves M. 231 - UFP (3), Martins S. \& Mariz I. 49 - UFP (5), Matos A.F. \& Goergen s.n. - EAC 12816 (5), Mendes A.P. \& Settini A.C. 374 - UFP (15), Mendes A.P. \& Settini A.C. 399 - UFP (5), Mendes A.P. \& Settini A.C. 400 - UFP (12), Mendes A.P. \& Settini A.C. 404 - UFP (20), Mendes A.P. \& Settini A.C. 415 - UFP (15), Mosca V.P. 16 - UFRN (17), Nunes T.A. 10 - MOSS (4), Oliveira O.F. 902 - MOSS (4), Oliveira O.F. et al. 1005 - MOSS (9), Oliveira O.F. et al. 1007 - MOSS (22), Oliveira O.F. et al. 1088 - MOSS (8), Oliveira O.F. et al. 1157 - MOSS (14), Oliveira O.F. et al. 1158 - MOSS (14), Oliveira O.F. et al. 1318 - MOSS (5), Oliveira O.F. et al. 1781 - MOSS (23), Oliveira O.F. et al. 1829 - MOSS (1), Oliveira O.F. et al. 1852 - MOSS (11), Oliveira O.F. et al. 290 - MOSS (23), Oliveira O.F. et al. 291 - MOSS (23), Oliveira O.F. et al. 538 - MOSS (2), Oliveira O.F. et al. 673 - MOSS (9), Oliveira O.F. et al. 674 - MOSS (9), Oliveira O.F. et al. 678 - MOSS (17), Oliveira O.F. et al. 679 - MOSS (17), Oliveira O.F. et al. 680 - MOSS (17), Oliveira O.F. et al. 72 - MOSS (23), Oliveira O.F. et al. 855 - MOSS (1), Oliveira O.F. et al. 856 - MOSS (18), Oliveira O.F. et al. 954 - MOSS (3), Oliveira R.C. \& Ferreira C.G.T. 1645 - MOSS (19), Oliveira R.C. 1581 - MOSS (5), Oliveira R.C. 2481 - MOSS (5), Oliveira R.C. et al. 1524 - MOSS (15), Oliveira R.C. et al. 1728 - MOSS (2), Oliveira R.C. et al. 1840 - EAC, MOSS (3), Oliveira R.C. et al. 1921 - MOSS (23), Oliveira R.C. et al. 2110 - MOSS (4), Oliveira R.C. et al. 2222 - MOSS (8), Oliveira R.C. et al. 2234 - MOSS (22), Oliveira R.C. et al. 2235 - MOSS (17), Oliveira R.C. et al. 2369 - MOSS (21), Oliveira R.C. et al. 2370 - MOSS (1), Oliveira R.C. et al. 2371 - MOSS (17), Oliveira R.C. et al. 2372 - MOSS (9), Oliveira R.C. et al. 2379 - MOSS (22), Oliveira R.C. et al. 2380 MOSS (15), Oliveira R.C. et al. 2381 - MOSS (24), Oliveira R.C. et al. 2392 - MOSS (9), Oliveira R.C. et al. 2395 - MOSS (3), Oliveira R.C. et al. 2396 - MOSS (17), Oliveira R.C. et al. 2397 - MOSS (1), Oliveira R.C. et al. 2398 - MOSS (4), Oliveira R.C. et al. 2399 - MOSS (22), Oliveira R.C. et al. 2402 - MOSS (4), Oliveira R.C. et al. 2405 - MOSS (4), Oliveira R.C. et al. 2407 - MOSS (21), Oliveira R.C. et al. 2415 - MOSS (17), Oliveira R.C. et al. 2417 - MOSS (1), Oliveira R.C. et al. 2418 - MOSS (22), Paiva S.A. s.n. - MOSS 532 (17), Paterno G.B.C. \& Loiola M.I.B. 113 - UFRN (1), Projeto Parque das Dunas 351 - MOSS (5), Projeto Parque das Dunas 6 - MOSS (5), Queiroz R.T. \& Cardoso M.Z. 596 - MOSS (1), Queiroz R.T. \& Cardoso M.Z. 596 - UFRN, MOSS (14), Queiroz R.T. \& Melo R.S. 182 - UFRN (23), Queiroz R.T. \& Queiroz F.R. 153 - MOSS, UFRN (1), Queiroz R.T. \& Zikán M. 598 - UFP (15), Queiroz R.T. 1063 - MOSS, UFRN (17), Queiroz R.T. 135 - UFRN (14), Queiroz R.T. 150 - UFRN, MOSS (22), Queiroz R.T. 302 - HUEFS (17), Queiroz R.T. 394 - UFRN (7), Queiroz R.T. 668 - HUEFS, UFP, UFRN (21), Queiroz R.T. 674 - HUEFS, UFP (23), Queiroz R.T. 718 - UFRN (19), Queiroz R.T. 767 - HUEFS, UFRN (23), Queiroz R.T. 786 - MOSS (14), Queiroz R.T. 786 - UFRN (14), Queiroz R.T. 824 - UFP, UFRN (1), Ribeiro A. \& Loiola M.I.B. 4 - MOSS (5), Ribeiro A. 2 - MOSS (1), Ribeiro A.R.O. \& Araújo A.M.S. 135 - MOSS (15), Ribeiro A.R.O. \& Araújo A.M.S. 136 - MOSS (3), Ribeiro A.R.O. \& Araújo A.M.S. 137 - MOSS (17), Ribeiro A.R.O. \& Araújo A.M.S. 139 - MOSS (13), Ribeiro A.R.O. \& Araújo A.M.S. 140 - MOSS (22), Ribeiro A.R.O. \& Araújo A.M.S. 142 - MOSS (4), Ribeiro A.R.O. \& Araújo A.M.S. 143 - EAC, MOSS (18), Ribeiro A.R.O. \& Araújo A.M.S. 147 - MOSS (21), Ribeiro A.R.O. \& Araújo A.M.S. 149 - MOSS (13), Ribeiro A.R.O. \& Silva A.S. 95 - MOSS (18), Ribeiro A.R.O. \& Silva A.S. 96 - MOSS (17), Ribeiro A.R.O. 101 - EAC, MOSS (13), Ribeiro A.R.O. 102 - EAC, MOSS (4), Ribeiro A.R.O. 103 - MOSS (3), Ribeiro A.R.O. 104 - MOSS (15), Ribeiro A.R.O. 105 - MOSS (17), Ribeiro A.R.O. 107 - MOSS (3), Ribeiro A.R.O. 116 - MOSS (3), Ribeiro A.R.O. 117 - MOSS 10885 (15), Ribeiro A.R.O. 118 - MOSS (17), Ribeiro A.R.O. 119 MOSS (13), Ribeiro A.R.o. 122 - MOSS (4), Ribeiro A.R.O. 125 - MOSS (3), Ribeiro A.R.O. 126 - MOSS (15), Ribeiro A.R.o. 127 - MOSS (17), Ribeiro A.R.O. 128 - MOSS (13), Ribeiro A.R.O. 129 - EAC, MOSS (4), Ribeiro A.R.O. 130 - MOSS (22), Ribeiro A.R.O. 131 - MOSS (18), Ribeiro A.R.O. 155 - MOSS (3), Ribeiro A.R.O. 156 - MOSS (15), Ribeiro A.R.O. 157 - MOSS (22), Ribeiro A.R.o. 158 - MOSS (17), Ribeiro A.R.O. 160 - MOSS (13), Ribeiro A.R.O. 161 - MOSS (18), Ribeiro A.R.O. 164 MOSS (4), Ribeiro A.R.O. 168 - EAC, MOSS (21), Ribeiro A.R.O. 17 - MOSS (3), Ribeiro A.R.O. 170 - MOSS, UB (10), Ribeiro A.R.O. 18 - MOSS (17), Ribeiro A.R.O. 19 - MOSS (15), Ribeiro A.R.O. 8 - MOSS (15), Ribeiro A.R.O. 81 - MOSS (15), Ribeiro A.R.O. 82 - MOSS (17), Ribeiro A.R.O. 91 - MOSS (3), Ribeiro A.R.O. 99 - MOSS (22), Ribeiro A.R.O. et al. 10 - MOSS (9), Ribeiro A.R.O. et al. 110 - MOSS (15), Ribeiro A.R.O. et al. 111 - MOSS (15), Ribeiro A.R.O. et al. 115 - MOSS (18), Ribeiro A.R.O. et al. 150 - MOSS (9), Ribeiro A.R.O. et al. 151 - MOSS (9), Ribeiro A.R.O. et al. 152 - MOSS (21), Ribeiro A.R.O. et al. 172 - MOSS (13), Ribeiro A.R.O. et al. 173 - MOSS (17), Ribeiro A.R.O. et al. 175 - MOSS (1), Ribeiro A.R.O. et al. 176 - EAC, 
MOSS (4), Ribeiro A.R.O. et al. 177 - MOSS (8), Ribeiro A.R.O. et al. 178 - MOSS (9), Ribeiro A.R.O. et al. 181 - MOSS (21), Ribeiro A.R.O. et al. 195 - MOSS (14), Ribeiro A.R.O. et al. 199 - EAC, MOSS (6), Ribeiro A.R.O. et al. 204 - MOSS (21), Ribeiro A.R.O. et al. 205 - MOSS (4), Ribeiro A.R.O. et al. 206 - MOSS (14), Ribeiro A.R.O. et al. 207 - MOSS (22), Ribeiro A.R.O. et al. 208 - MOSS (13), Ribeiro A.R.O. et al. 210 - MOSS (4), Ribeiro A.R.O. et al. 213 - MOSS (10), Ribeiro A.R.O. et al. 214 - MOSS (22), Ribeiro A.R.O. et al. 23 - EAC, MOSS (15), Ribeiro A.R.O. et al. 247 - UB, MOSS, RB (24), Ribeiro A.R.O. et al. 30 - EAC, MOSS (11), Ribeiro A.R.O. et al. 4 - MOSS (14), Ribeiro A.R.O. et al. 44 - EAC, MOSS (14), Ribeiro A.R.O. et al. 49 - EAC, MOSS (16), Ribeiro A.R.O. et al. 52 - EAC, MOSS (22), Ribeiro A.R.O. et al. 55 - MOSS (11), Ribeiro A.R.O. et al. 62 - EAC, MOSS, UFRN (5), Ribeiro A.R.O. et al. 64 - EAC, MOSS (3), Ribeiro A.R.O. et al. 68 - EAC, MOSS (22), Ribeiro A.R.O. et al. 69 - EAC, MOSS (20), Roque A.A. \& Oliveira A.C.P. 47 - MOSS (4), Roque A.A. \&. Oliveira A.C.P. 55 - UFP, UFRN (15), Roque A.A. 1051 - UFRN (24), Roque A.A. 1053 - UFRN (17), Roque A.A. 1054 - UFRN (22), Roque A.A. 1055 - UFRN (21), Roque A.A. 189 UFRN (1), Roque A.A. 210 - UFP, UFRN (4), Roque A.A. 252 - UFP (15), Roque A.A. 267 - UFP, UFRN (17), Roque A.A. 277 UFRN (2), Roque A.A. 346 - UFRN, MOSS (17), Roque A.A. 370 - UFRN (15), Roque A.A. 382 - UFRN (3), Roque A.A. 417 - UFRN (7), Roque A.A. 489 - UFRN, MOSS (23), Roque A.A. 502 - UFRN, MOSS (19), Roque A.A. 661 - UFRN (19), Roque A.A. 670 UFRN (23), Roque A.A. 699 - UFRN (3), Roque A.A. 705 - UFRN (23), Roque A.A. 716 - UFRN (15), Roque A.A. 735 - UFRN (17), Sayonara et al. s.n. - UFRN 8028 (3), Sena V.R.R. et al. 103 - UFRN (12), Silva A.S. et al. 3 - MOSS (3), Silva G.G. da \& Batista S. s.n. - MOSS 10154 (15), Silva G.H.G. et al. 12 - MOSS (17), Silva G.H.G. et al. 14 - MOSS (3), Silva G.H.G. et al. 23 MOSS (17), Silva G.H.G. et al. 27 - MOSS (22), Silva J.M. da 2 - MOSS (17), Silva J.O.N. et al. 28 - UFRN (15), Silva M.L. 265 - MOSS (2), Soares R.M. 22 - UFRN, MOSS (18), Soares R.M. et al. 67 - MOSS, UFRN (11), Sousa F.S.R. 23 - UFRN (15), Sousa R.A. 3 - MOSS (3), Tavares S. 367 - UFP (5), Trindade A. s.n. - MOSS 12440 (7), Trindade A. s.n. - UFRN 1822, MOSS 11740 (7), Vasconcelos S.H. 19 - MOSS (2), Vodicka M.R. \& Oliveira O.F. 73 - MOSS (5). 